\title{
Расширяющееся культурное пространство: пример калмыцкой диаспоры (буддизм и идентичность, миграции и современные технологии)"
}

\author{
Эльза П. Бакаева \\ Калмыцкий научный центр Российской академии наук, \\ Российская Федерация
}

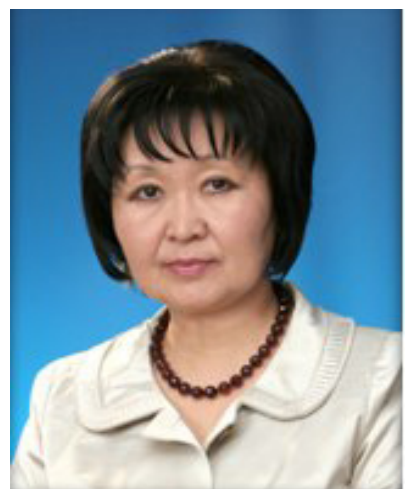

В статье анализируется культурное пространство, определенное разными территориями проживания калмыков, на примере калмыцкой общины в США. Показаны разноуровневые проявления связей территорий проживания калмыков в пространстве их культуры, определенных спецификой исторической судьбы этноса. Во времена «железного занавеса» проявления этих связей обусловлены спецификой истории: в период ссылки калмыцкого народа в восточные районы СССР в результате противозаконной насильственной депортации культурное пространство было «разорвано», как был разобщен сам народ: связи культурного пространства нашли проявление только в памяти о «материнском этносе» среди американских калмыков и их попытках содействовать восстановлению автономии Калмыкии, означавшему и возобновление связей; в период после восстановления автономии Калмыкии, несмотря на «закрытость пространства», все же прослеживаются отдельные проявления связей на уровне культуры.

Современный период, начавшийся в 1990-х г2., показывает расширение культурного пространства, его интенсивное наполнение благодаря использованию интернет-технологий. В статье также рассматривается культурное пространство калмыцкой диаспоры в аспекте объединяющих и специфических факторов в реализации связи конфессиональной и этнической идентичности; освещаются современные процессы, способствующие формированию единого культурного конфессионального пространства, и способствующие этому факторы. В контексте осмысления новых социальных условий и развития информационных технологий также проанализированы некоторые символы, использующиеся в жизни калмыцкой диаспоры в США.

Источниками исследования послужили научные публикации, интернет-источники, сообщения СМИ, а также непосредственные наблюдения автора во время пребывания среди калмыцкой диаспоры США в 2012 г. и в процессе активной переписки с ее представителями на протяжении 2012-2019 г2.

Ключевые слова: калмыки; Республика Калмыкия; калмыцкая диаспора; калмыцкая диаспора в США; культурное пространство; пространство; культурные связи; конфессиональная идентичность; этническая идентичность; буддизм; символы

"Исследование проведено в рамках государственной субсидии - проект «Комплексное исследование процессов общественнополитического и культурного развития народов Юга России» (регистрационный номер АААA-A19-119011490038-5).

\section{Для цитирования:}

Бакаева Э. П. Расширяющееся культурное пространство: пример калмыцкой диаспоры (буддизм и идентичность, миграции и современные технологии) [Электронный ресурс] // Новые исследования Тувы. 2019, № 3. URL: https:// nit.tuva.asia/nit/article/view/869 (дата обращения: дд.мм.гг.). DOI: 10.25178/nit.2019.3.10 научного центра РАН. Адрес: 358000, Россия, г. Элиста, ул. им. И. К. Илишкина, д. 8. Тел.: +7 (84722) 3-55-15. Эл. адрес: bakaevaep@kigiran.com ORCID ID: 0000-0002-5188-1202

Bakaeva Elza Petrovna, Doctor of History, Deputy Director for Research, Kalmyk Scientific Center, Russian Academy of Sciences. Postal address: 8 Ilishkin St., 358000 Elista, Russian Federation. Tel.: +7 (84722) 3-55-15. E-mail: bakaevaep@kigiran.com 


\title{
The expanding cultural space: a case study of the Kalmyk diaspora (Buddhism and identity, migrations and modern technologies)"
}

\author{
Elza P. Bakaeva \\ Kalmyk Scientific Center of the Russian Academy of Sciences, \\ Russian Federation
}

\begin{abstract}
The article analyzes the cultural space defined by different Kalmyk-inhabited territories with a special insight into the life of the U.S. Kalmyk community. It outlines the multi-level ties between Kalmyk-inhabited territories within their common cultural space determined by specific historical destinies of the ethnicity. In the "Iron Curtain" period, any such ties were dramatically dependent upon the misfortunes of history. The illegal act of forced deportation of the Kalmyk population to the Eastern regions of the USSR 'tore apart' this cultural space as it scattered the ethnicity itself. Ties with the cultural space manifested themselves only in somewhat persistent historical memory about the 'mother ethnicity' cultivated by American Kalmyks, and in their attempts to facilitate the restoration of Kalmykia's autonomy that would once again reinforce these mutual ties. When the autonomy was reestablished, some cultural contacts were reinstalled, even though the cultural space remained closed off.

The contemporary period (from the 1900s onwards) is a time when the cultural space expanded, enriched through the use of Internet technologies. The article also examines the cultural space of the Kalmyk diaspora in terms of certain unifying and distinguishing factors which set up a link between confessional and ethnic identities. The author also sheds light on current processes facilitating the development of an integrated cultural and confessional space, and factors contributing to these developments. Interpreting the newly emerged social conditions and information technologies, the article also analyzes some of the symbols accepted by the U.S. Kalmyk diaspora.

Sources for the study include scholarly publications, Internet resources, media articles, as well as the author's field observations during her 2012 stay with the U.S. Kalmyk diaspora and the active epistolary exchange since then.
\end{abstract}

Keywords: Kalmyks; Republic of Kalmykia; Kalmyk diaspora; U.S. Kalmyk diaspora; cultural space; space; cultural ties; confessional identity; ethnic identity; Buddhism; symbols

"The research was performed with a government subsidy - project 'Socio-Political and Cultural Development of South Russia's Peoples: a Comprehensive Research of Respective Processes' (State Reg. No. AAAA-A19-119011490038-5).

\section{For citation:}

Bakaeva E. P. The expanding cultural space: a case study of the Kalmyk diaspora (Buddhism and identity, migrations and modern technologies). The New Research of Tuva. 2019, № 3. URL: https://nit.tuva.asia/nit/article/view/869 (access date ....). DOI: $10.25178 /$ nit.2019.3.10

\section{Введение}

Пространство - одна из основных категорий культуры, которую изучают специалисты в разных областях науки, в том числе этнологи и антропологи (Тишков, 2003; Малькова, Тишков, 2009, 2010; Жуковская, 1988 и др.). В нашей статье под культурным пространством подразумеваются территория или ареал, в котором протекают этнические культурные процессы и реализуется этническая культура. Одновременно культурное пространство выступает и как совокупность культурных процессов, форма бытования культуры в определенных границах. В развитии культурного пространства наблюдают распространение культуры, последовательное освоение пространства окружающей среды и обозначение его границ. Оно обладает объединяющим началом и выполняет соответствующую функцию, оказывая влияние на идентичность носителей культуры. Культурное пространство включает и ареалы, освоенные этнической группой, и более широкое пространство, включающее среду, в которой функционирует этническая культура.

Пространство калмыцкой культуры - это территория, включающая ареалы проживания калмыков, в которых реализуется их этническая культура. В различные периоды это пространство включало разные территории, в том числе - компактного расселения этноса и проживания локальных групп. Для калмыков «материнской культурой» выступает культура калмыцкого этноса, сложившегося на 
основе ойратов, прикочевавших в XVII в. на юг России. Если же углубиться в историю, то «материнской культурой» для калмыцкой культуры является культура ойратов. Культурное пространство выполняет связывающую функцию, объединяя разные группы с единой или схожей идентичностью. В наши дни пространство калмыцкой культуры объединяет территории проживания калмыков в России (прежде всего в Республике Калмыкия) и ареалы калмыцких общин во Франции (Aubin, 1968) и в США (Гучинова, 2004; Четырова, 2010 и др.).

По мнению Е.В.Орловой, «Понимание культурного пространства как пространства бытования культуры отличается <..> тем, что в своих границах оно не совпадает с другими пространствами»; «культурное пространство полифункционально, так как реализует функционирование общественных систем, обеспечивает пространственное функционирование культуры, поскольку выступает как ареал, в котором протекает жизнь культуры» (Орлова, 2010: 47).

Понятие границы, отделяющей внутреннее пространство от внешнего, имеет значение для любого культурного пространства, но проблема состоит в самом определении последнего как локального или более широкого ареала (Лотман, 1999: 362; Малькова, Тишков, 2009: 4-21; Малькова, Тишков, 2010; Орлова, 2010). В условиях глобализации, демократизации общества и с развитием информационных технологий границы становятся более прозрачными или гибкими. Культурное пространство же расширяется вместе с горизонтальным движением, проявляющимся как физически (в миграционных процессах), так и виртуально (через объединяющую функцию интернет-публикаций).

Исследователями предлагаются различные подходы к изучению культурного пространства.В. А. Тишков отмечает, что существует много разных его категорий, выделяя геопространство, социальное, поведенческое, информационное и электронное пространство и т. д. (Тишков, 2003: 19). О.И. Иванов обращает внимание на то, что культурное пространство - одно из полей (наряду с экономическим, политическим, образовательным и т. д.) единого социального пространства социального мира, которое создают «социальные акторы, производя и воспроизводя культурные продукты», они же создают наложение полей (Иванов, 2015: 19-22). Е. В. Орлова выделяет «две ипостаси» культурного пространства: концептуальное культурное пространство («культурные системы», то есть идеи и ценности, предаваемые через традиции) и пространство бытования культуры («осмысленный образ этих систем», имеющий реальные измерения) (Орлова, 2010: 48). По ее мнению, культурное пространство является механизмом «окультуривания» естественного пространства (там же).

Религиозный фактор в пространственном развитии культуры занимает одно из ведущих мест. С миграциями же происходит и пространственное развитие конфессиональной культуры, так как «подавляющая часть иммигрантов - носители определенной религиозности, непосредственно связанной с коренной этнической и культурной идентичностью» (Каргина, 2014: 164).

Интерес к истории и культуре группы эмигрантов-калмыков в США со стороны общества наглядно демонстрирует поисковой запрос в Интернете - «калмыки в США», в итоге такого запроса 3 мая 2019 г. у нас появился результат - около 1,5 млн записей.

В статье рассматривается культурное пространство калмыцкой диаспоры в США в ее связи с культурным пространством «материнского этноса», объединяющее этнические группы с разноуровневой идентичностью. В задачи данной работы входит анализ проявлений объединяющей функции культуры в особых условиях территориального и политического отрыва группы от основного этноса, роли буддизма и конфессиональной идентичности, других паттернов калмыцкой культуры в жизни калмыцкой диаспоры в США - в контексте осмысления новых социальных условий и развития информационных технологий. Источниками исследования послужили разнообразные материалы из научной литературы, интернет-источников, а также непосредственные наблюдения автора во время пребывания среди калмыцкой диаспоры США в 2012 г. и в процессе активной переписки с ее представителями на протяжении 2012-2019 гг.

\section{Калмыки в США и пространство их этнической культуры на разных этапах развития внутренних связей}

В истории калмыцкого народа имели место два исхода - периодов Гражданской и Второй мировой войн. Калмыки-эмигранты в Европе предпринимали активные попытки по сохранению культуры (Гучинова, 2004; Топалова, 2017, 2019 и др.). В 1951 г. разнородная в социальном и субэтническом отношении группа калмыков появилась в США и поселилась в г. Филадельфии и г. Хауэлле. А на их родине в СССР в 1943-1957 гг. калмыки в результате насильственной депортации были дисперсно расселены по всей восточной части страны. 
В этот период общественная организация «Калмыцкий комитет» пыталась информировать мировую общественность о судьбе калмыцкого народа в СССР, делегаты от нее добрались до ООН и Государственного департамента США. Венцом деятельности комитета стала резолюция первой конференции азиатских и африканских народов в Бандунге (1955 г.) о положении буддистов-калмыков в СССР (Наминов-Бурхинов, 1997: 13-15; Четырова, 2010: 335). На наш взгляд, анализ этой деятельности калмыцкой эмиграции позволяет делать вывод о наличии ментальной связи и памяти о «материнском этносе», который находится в дисперсном состоянии, лишенном компактного расселения: культурное пространство «разорвано» (находится в дисперсном состоянии, как рассеян народ), но оно существует. Эта связь с культурным пространством проявлялась и в других сферах, прежде всего в конфессиональной культуре, о чем будет сказано далее.

Следующий этап в развитии культурного пространства, связанного с ареалами проживания калмыков, определен такими маркерами, как восстановление автономии Калмыкии (1957 г.) и возвращение народа из ссылки. Связи эмигрантов с населением СССР в этот период были затруднены (Антошин, 2005 и др.); калмыки в США не знали о судьбе родственников в СССР ${ }^{1}$ Как узнали в США о возвращении калмыков на родину, мы узнаем из воспоминаний калмыков - участников VII Всемирного фестиваля молодежи и студентов «За мир и дружбу». Делегат из Калмыкии В. П. Дорджиев в 2000 г. вспоминал о дискуссиях во время фестиваля, рассказах о восстановлении автономии и трудностях, о «каверзных вопросах» о выселении калмыков, а также о встрече «с калмыком из Америки Алексеем Иванчуковым, с которым мы подружились и встретились через 31 год в Элисте» (Дорджиев, 2000: 30). Буквально же информация о возвращении калмыков на свои родные территории была передана сородичу из США на родном языке: по воспоминаниям А. С. Иванчукова, «... в Австрии проходил международный фестиваль молодежи и студентов. <...> я расспрашивал всех из советской делегации, есть ли промеж них калмыки. <...> разыскали советского калмыка, в то время секретаря обкома ВЛКСМ. Когда я увидел Владимира Дорджиева, он мне первым делом сказал: „Мадн шинкән ирихәвидн“ (Мы только что вернулись), и я от радости забыл про свой антикоммунизм, мы обнялись и о политике не говорили» (Гучинова, 2004: 179-180; курсив источника. - Э. Б.). Фраза «Мы только что вернулись», не привязанная к конкретной ситуации встречи, понятна двум калмыкам, проживающим в разных концах света: эвфемизмы явление, характерное для калмыцкой культуры. Двойное иносказание (неизвестный окружающим их людям калмыцкий язык и косвенное значение фразы) передает значимость вести, которую повезет в США А. Иванчуков, и отражает единство категорий и понятий в пространстве культуры.

Возвращение калмыцкого народа на родину означало и восстановление культурного пространства, связей между людьми и территориями, что проявлялось в разных сферах. Среди знаковых событий в жизни общины калмыков США того периода - выпуск фильма «Американцы из Джунгарии» (1960-е гг. $\left.{ }^{2}\right)$ (консультанты Н. Адьянов, Н. Нембриков, А. Борманжинов). Наиболее значимые факторы идентичности калмыков: религия, национальный язык, антропологический тип, традиционное хозяйство - перечисляются в самом начале фильма: сначала утверждается конфессиональная буддийская идентичность, затем в фильме звучит калмыцкая речь и слышна популярная песня «Нюдля», разъясняется ${ }^{3}$, что «Они - монголы, по своему расовому происхождению близкие Великому Чингисхаану», и следует текст титров: «Наша прародина находится в Джунгарии в северной части китайской провинции Синьцзян <...> Калмыки <...> занимались разведением лошадей, а также овец и верблюдов $<. .>$ они были обращены в буддизм монахами-ламами из Тибета <...> Сегодня, находясь на полмира от Джунгарии, в Нью-Джерси, калмыки остаются буддистами-ламаистами».

Отметим три важных момента в «зачине» фильма, характеризующего пространство культуры калмыцкой общины США в начале 1960-х гг.: 1) Религиозная идентичность рассматривается как главный связующий фактор калмыков с культурой их прапредков; 2) Комментарии демонстрируют, что калмыки США находились в пространстве русской культуры (в одном из титров так и записано: «Играет русская музыка (на самом деле играет Калмыцкая)» (хотя диктор говорит по-английски «Играет русская музыка») 5 . 3. В сценарии фильма прослеживается связь мигрантской группы с «материнским» этносом.

\footnotetext{
${ }^{1}$ http://khurul.ru/2009/09/telo-tulku-rinpoche-o-vizite-v-mongoliyu/ (дата обращения 15.02.2019).

${ }^{2}$ В титрах фильма не указан год его выпуска.

3 Текст комментария к фильму читается на английском языке, в кадрах фильма одновременно появляются титры (перевод зачитываемого текста) на русском языке.

${ }^{4}$ https://www.youtube.com/watch?v=Wr7LmkwwR8E (дата обращения 01.05.2019).

${ }_{5}^{5}$ Мигранты только изучали английский язык. Один из кадров сопровождают титры: «Я разговариваю на русском, калмыцком, немецком, монгольском и немного на английском». Известно, что калмыкам, расселенным на территории Германии, пришлось доказывать свое европейское происхождение («было доказано, что калмыки социально „белые“, потому что они жили в Европе и имели свою государственность» (Гучинова. 2004: 144)) в связи с особенностями иммиграционного законодательства США (Bormanshinov, 1987: 6).
} 
О происходящих в СССР событиях косвенно говорится в эпизоде, сравнимом с фразой-«эвфемизмом» «Мы только что вернулись», в которой была передана в иноязычном окружении калмыком калмыку новость о восстановлении автономии Калмыкии: уже в первом эпизоде, следующем за общими кадрами и сценой в храме, один мужчина спрашивает у другого на родном языке: «Как дела?» Ответ: «Хорошо». Следующий вопрос: «Вечером будешь танцевать?» ${ }^{1}$ - сопровождает зачин песни «Нюдля», начинающейся со слов «Вечерней осенней прохладой...» На первый взгляд, обычные фразы, которыми перебрасываются мужчины в кадре, предстают как тонкая игра слов и смыслов, отсылающая к обсуждению состояния общества - здесь и там. Иносказательный смысл этого эпизода в фильме передан через вопрос о предстоящем собрании общины с танцами и мотива этой вечеринки. Выбор песни «Нюдля» символичен: он действительно свидетельствует о том, что у калмыков все «хорошо» - не только в общине в США, о которой создан фильм ${ }^{2}$, но и на родине в Калмыкии. Песня «Нюдля» сложена в 1942 г. $^{3}$ и не могла быть включена без причины в фильм. Широко известной она стала после ее исполнения У. Б. Лиджиевой в годы войны и особенно - после включения калмыцких песен в ее исполнении в программу Всесоюзного радио в 1956 г. «Первая ласточка о потеплении в отношении калмыков - песнь Нюдля на союзном радио» - так характеризуется теперь в социальных сетях значение песни в конце $1950-$ х гг. ${ }^{4}$ «...голос Родины <...> был конкретизирован через голос певицы У. Б. Лиджиевой, чья <...> песня на родном языке заставила плакать всех калмыков на чужбине <...>. И тех, кто вспоминал родную степь, и тех, кто родился, вырос вдали от степей и в первый раз музыку родной земли услышал по радио» (Ханинова, 2008: 92). В фильме «Американцы из Джунгарии» также исполняется песня «Нюдля»; «голос Родины» звучит, передавая общественное настроение в диаспоре калмыков и связывая пространство культуры через культурные смыслы, заложенные в культурных явлениях.

Таким образом, в сценарии реализуется мысль о позитивных изменениях в обществе, в том числе достигнутых и благодаря буддийской вере. Несмотря на географическую отдаленность группы мигрантов от родины, в этом эпизоде можно слышать ее участие в судьбе калмыков СССР - и в такой закодированной форме реализуется общее культурное пространство, несмотря на практически полное отсутствие связей между калмыками в разных странах.

До начала 1990-х гг. общая политическая ситуация между странами Запада и СССР, характеризуемая часто как «железный занавес», не менялась. Но, как можно видеть даже в фильме 1960-х гг., в культурном пространстве, несмотря на границы территориальные и политические, прослеживается родство культурных явлений.

С 1990-х гг. начался другой этап эмиграции в США, и толчком к ней стал визит 18-27 августа 1990 г. в Калмыкию официальной делегации объявленного побратимом Элисты г. Хауэлла, принявшей участие в праздновании 550-летия эпоса «Джангар».

Будущее калмыцкой диаспоры представлялось в конце XX в. смутным: «...маловероятно, чтобы эта малочисленная этническая группа смогла сохранить свою неповторимую национальную самобытность» (Bormanzhinov, 1987: 15). Но и в наши дни калмыцкая диаспора демонстрирует устойчивость. Она множится численно, ее культурное пространство расширяется и расширяет границы калмыцкой культуры.

Численность калмыков в США не поддается точному учету. В начале 1960-х гг. было около 1000 калмыков (Rubel, 1967; Bormanzhinov, 1987: 5). В г. Хауэлле в 2010 г. проживали 2309 «азиатов», были представлены калмыками 5 .

Миграционный отток из Калмыкии фиксируется на протяжении всего постсоветского периода (Убушаев, 2009; Намруева, 2011, 2013; Баранова, 2016 и др.). Журналисты бьют тревогу: ежегодно часть населения уезжает в экономически более развитые регионы и страны зарубежья 6 .

\footnotetext{
1 «Калмыки любят танцевать, и большие праздники всегда сопровождаются танцами...» (Гучинова, 2004: 251). Даже празднование Цаган сар американские калмыки называют «Тsagan dance». Поэтому вопрос к калмыку, будет ли он танцевать вечером, в данном контексте означает «Будешь ли участвовать в вечеринке с танцами?»

${ }^{2}$ Фильм о небольшой мигрантской группе, созданный американским кинорежиссером, «по закону жанра» завершается утверждением о достижении ими желанной земли, откуда мигранты не собираются никуда переселяться.

${ }^{3}$ Автор - Б. Джимбиев.

${ }^{4}$ ok.ru/dzhungariy/topic/66298011074611 (дата обращения 01.05.2019).

${ }^{5}$ www.twp.howell.nj.us/244/History-of-Howell-Township (дата обращения 15.04.2019).

${ }^{6}$ Калмыкия вымирает. Реальная численность населения в 2019 году. Жители массово уезжают из республики (2019) [Электронный ресурс]//О.Новости. Общество. Политика. Мнения. Аналитика. Рейтинги. 15 февраля. URL: http://obzor.io/2019/02/15/ kalmykiya-vymiraet-realnaya-chislennost-naseleniya-v-2019-godu-57810/ (дата обращения 15.05.2019).
} 
Как отмечается в одном из чатов, «в настоящее время делаются робкие попытки объединить калмыцкую диаспору в США в одно целое, так как ее количество превысило 20-30 тыс. человек» ${ }^{1}$ Эти данные отражают общие представления калмыков США о своей численности, сведения о которой в разных источниках сильно различаются. Косвенно о числе мигрантов новой волны свидетельствует следующее: в Facebook группа «Kalmyks in USA / Калмыки в США», общение в которой происходит, в основном, на русском языке, объединяет 1157 участников ${ }^{2}$, группа «Калмычки за рубежом» -732 участниц ${ }^{3}$ в 2017 г. в Нью-Йорке в зале городской администрации Бруклина состоялась «Первая Ойратмонгольская конференция» ${ }^{4}$.

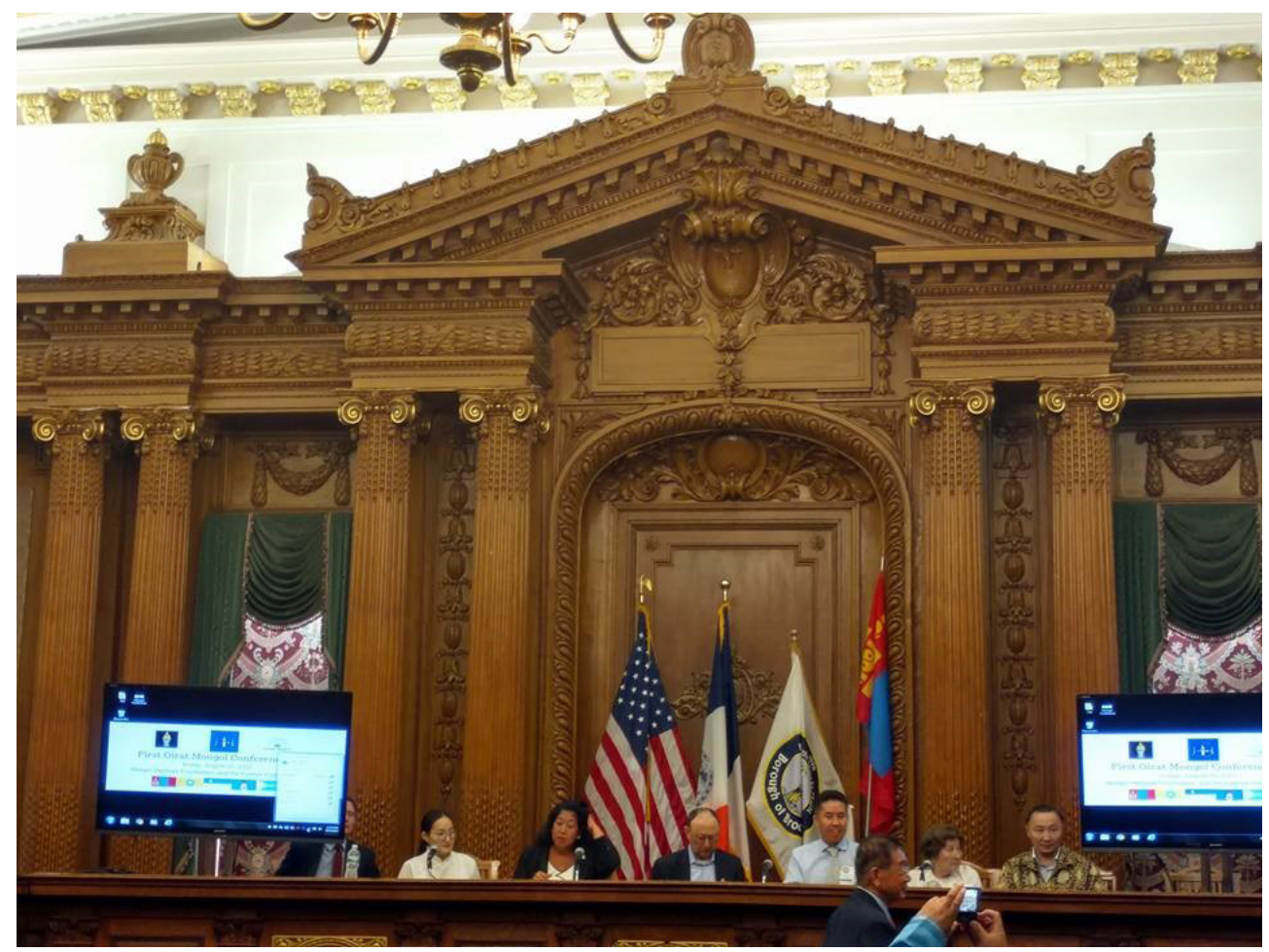

Фото 1. Президиум Первой Ойрат-монгольской конференции. 2017 г. Скриншот из видеозаписи компании «Ulan Zalata Producrions» на Youtube 5 .

Photo 1. Presidium of the First Oirat-Mongolian conference. 2017.

Screenshot from a YouTube video by Ulan Zalata Productions.

Возросшая численность калмыцкой общины побудила ее представителей заняться организацией общественных объединений. В 2013 г. в Нью-Йорке создан культурно-религиозный центр «Kalmyk Project», объединивший представителей новой волны эмигрантов и нацеленный на сохранение и развитие национальной культуры, языка и религии калмыков ${ }^{6}$.

В 2015 г. в Хауэлле (штат Нью Джерси) состоялось первое мероприятие, ознаменовавшее создание Kalmyk Youth Coalition ('Объединение калмыцкой молодежи'), лидеры которого утверждают: «Предоставляя платформу для изучения калмыцкой идентичности, мы стремимся стать ресурсом для калмыцкого сообщества. Посредством развития лидерства, образования и обучения мы стремимся содействовать пониманию истории и сохранению нашего языка и культуры»7. В задачи организации

\footnotetext{
${ }^{1}$ kalmchat.com/2016/12/05/kratkaya-istoriya-sozdaniya-kalmyckoj-diaspory-v-ssha/ (дата обращения 15.12.2018).

${ }^{2}$ www.facebook.com/groups/592230780861766/; см. также: Kalmyks in USA / Калмыки в США. Группа для калмыков, проживающих в США // https://vk.com/club148928789 (дата обращения 05.04.2019).

${ }^{3}$ https://www.facebook.com/groups/181073055632759/ (дата обращения 15.06.2019); см. также: http://riakalm.ru/news/culture/9490-kalmychki-sletelis-s-raznykh-stran-mira-chtoby-vstretitsya-vzhivuyu (дата обращения 15.05.2019)).

4 www.youtube.com/watch?v=atH03Mxu7Is\&list=PLovI4O102mEUN15-vr_zbE0JvEbQ33SJf\&t=0s \&index=8; www.youtube.com/ watch?v=dV8ylTwukK8; www.youtube.com/watch?v=gdtKO8JRBLs (дата обращения 05.05.2019).

${ }^{5} \mathrm{https}$ ://www.youtube.com/watch? $=$ =atH03Mxu7Is\&list=PLovI4O102mEUN15-+vr_zbE0JvEbQ33SJf\&t=0s \&index=8 (дата обращения 15.04.2019).

6 www.bumbinorn.ru/hamagmongol/1165135274-v-nyu-yorke-otkrylsya-kulturno-religioznyy-centr-kalmyk-project_48654.html; khurul.ru/2013/02/telo-tulku-rinpoche-vstretilsya-s-kalmykami-kulturno-religioznogo-centra-kalmyk-project-v-nyu-jorke/; www. facebook.com/groups/373806586051386/516654731766570/ (дата обращения 05.05.2019).

${ }^{7}$ https://www.youtube.com/watch?v=aEilLdsMy4U (дата обращения 05.05.2019).
} 
входит «объединение молодых калмыков Америки, Европы, Азии и России вокруг идеи возрождения национальной культуры и изучения буддизма» ${ }^{1}$. Проект нацелен на расширение пространства калмыцкой культуры: «Число молодежи в калмыцкой диаспоре США значительно возросло. Поэтому есть достаточно широкий запрос на культурный и религиозный обмен между молодыми калмыками, есть интерес к совместным проектам, объединяющим членов диаспоры и молодежь в самой Калмыкии»². Их лидером является Шаджин-лама Калмыкии, Почетный представитель Далай-ламы XIV в России, Монголии и странах СНГ Тэло Тулку Ринпоче ${ }^{3}$, и потому изображение Центрального хурула Калмыкии, как и флага Калмыкии, присутствует на странице группы в Facebook. Эксперт П. Голод считает: «...следует поддерживать общение молодых людей, разделенных госграницами, но не переставших воспринимать себя как единое целое <...> Интерес к взаимному общению между членами калмыцкой диаспоры за рубежом и их земляками из Калмыкии всегда был очень высок <...> сегодня такое общение может стать перспективным направлением общественной дипломатии, позволяющим продвигать позитивный образ России в США и ЕС через взаимовыгодный межкалмыцкий диалог» ${ }^{4}$

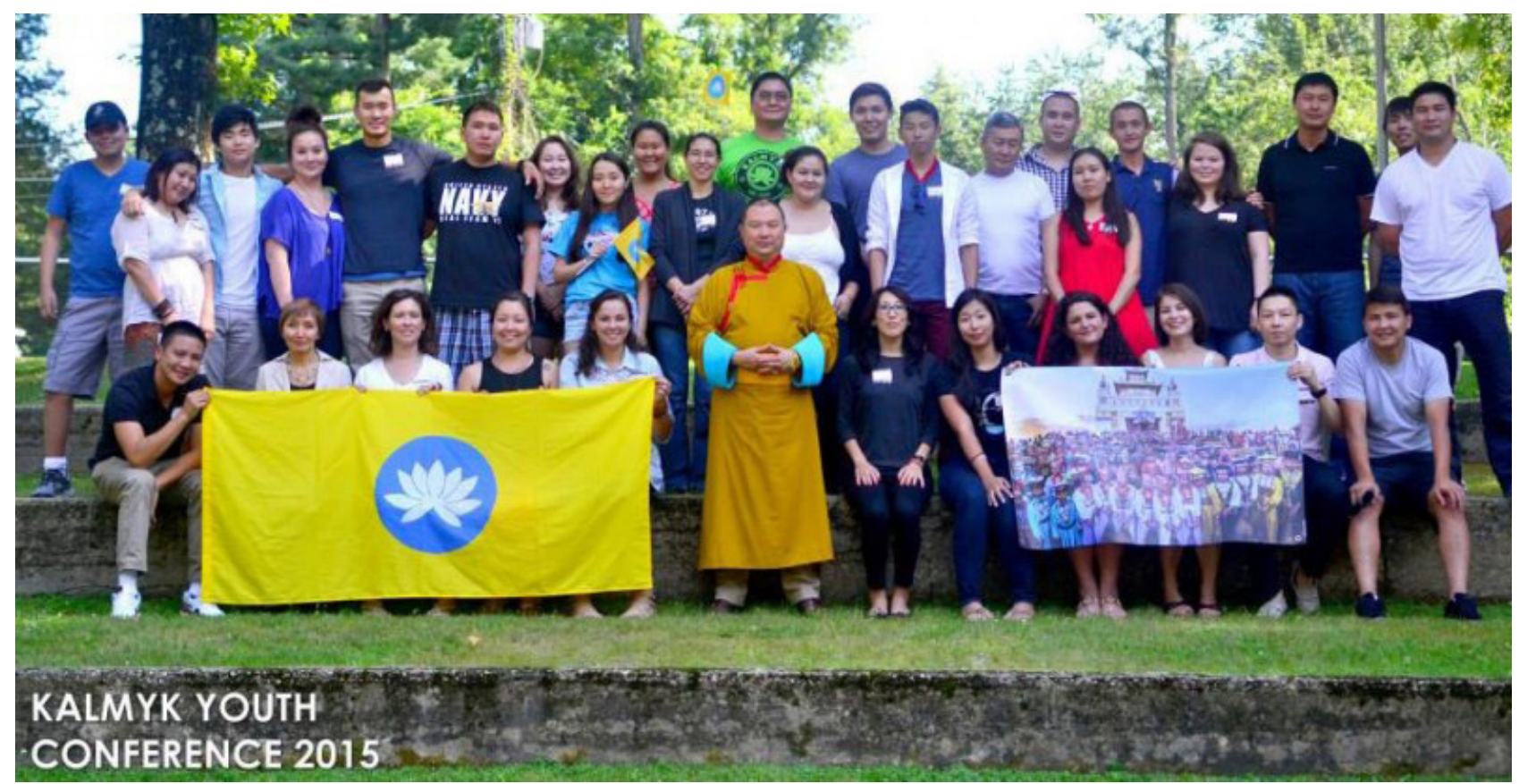

Фото 2. Участники Первой конференции Объединения калмыцкой молодежи, 2015 г. Фото с сайта объединения 5 . Photo 2. Participants of the $1^{\text {st }}$ conference of the Kalmyk Youth Coalition, 2015. Photo courtesy of the association's website.

В конференциях объединения принимают участие активисты, докладчиками выступают известные деятели культуры: Тэло Тулку Ринпоче; бывший руководитель организации «Иткл“» ('Вера’) В. Боков; куратор Художественного музея Рубина (Rubin Museum of Art, New York) Е. Пахутова; представитель калмыцкой диаспоры Е. Ремилева и др. ${ }^{7}$

${ }^{1}$ Серенко, А. (2015) Американских калмыков потянуло к родной культуре [Электронный ресурс] // Независимая газета. 30.07.

URL: http://www.ng.ru/regions/2015-07-30/5_kalmyk.html (дата обращения 15.02.2019).

${ }^{2}$ Там же.

${ }^{3}$ Болдуринова, Е. (2015) Тэло Тулку Ринпоче: в мире всё циклично... С пресс-конференции республиканским СМИ [Электронный ресурс] // Калмыцкий Центральный Буддийский монастырь "Геден Шеддуп Чой Корлинг". URL: http://khurul. ru/2015/08/telo-tulku-rinpoche-v-mire-vse-ciklichno\%E2\%80\%A6-s-press-konferencii-respublikanskim-smi/ (дата обращения 01.04.2019).

${ }^{4}$ Серенко, А. (2015) Американских калмыков потянуло к родной культуре [Электронный ресурс] // Независимая газета. 30.07. URL: http://www.ng.ru/regions/2015-07-30/5_kalmyk.html (дата обращения 15.02.2019).

${ }^{5}$ https://kalmykyouth.tumblr.com/ (дата обращения 15.04.2019).

${ }^{6}$ Общественная организация «Иткл» создана в г. Элисте в 2010 г., главными задачами ее являлись пропаганда, сохранение калмыцкого языка и культуры (Боваева, Н. (2011) «Иткл» возрождает калмыцкий язык // Хальмг үнн. 26.02. [Электронный ресурс] // http://halmgynn.ru/19-itkl-vozrozhdaet-kalmyckiy-yazyk.html (дата обращения 05.05.2019); см. также: http://khurul.ru/2015/02/molodezhnyj-blagotvoritelnyj-koncert-posvyashhennyj-cagan-sar-sostoitsya-27-fevralya/ дата обращения 15.12.2018); https://www.youtube.com/watch?v=sUC4-weT0To (дата обращения 15.04.2019).

${ }^{7}$ https://kalmykyouth.tumblr.com/ (дата обращения 15.04.2019); http://www.facebook.com/groups/KalmykYouthConference/ (дата обращения 15.04.2019). 
Первым форумам калмыцкой молодежи в США оказали содействие общество «Kalmyk Brotherhood Society», хурул Ницян Чойпэл Линг и хурул Ташилунпо․․ㅋо пример дает повод задуматься о роли буддийской идентичности в деле сохранения этнического самосознания.

\section{Хурулы американских калмыков и субэтническая идентичность. Современная община калмыков в США}

Прибыв в начале 1950-х гг. в США, калмыки вскоре объединились в три общества согласно субэтнической принадлежности: донские калмыки-бузава в Филадельфии («Калмыцкое братство») и в Хауэлле (община Барун-хурула), а также астраханские калмыки (Rubel, 1967: 111) (представители этнических групп дербетов и торгутов, которые в 1961 г. основали «калмыцко-буддийское благотворительное общество» «Ниицән» ('Единство') (Гучинова, 2004: 156, 159)). «Четвертый блок, ориентированный на академический буддизм, был создан ламой, заинтересованным в продвижении этих аспектов и модернизации буддизма» (Rubel, 1967:111). Речь идет о «Ламаистском буддийском монастыре Америки» (ЛБМА, ныне Тибетский буддийский исследовательский центр (ТБИЦ)), основанном в 1958 г. калмыком - геше Вангъялом (1901-1983)².

Религиозная составляющая для идентичности калмыков являлась значимой: первые калмыкиэмигранты открыли буддийский храм в г. Белграде уже в 1923 г. в арендованном помещении, затем добились разрешения на строительство и к 1929 г. благодаря поддержке калмыков со всей Европы и местных властей построили и освятили большой храм, вмещавший 150 человек (Миленкович, 1998), и потому сразу после прибытия в США началось активное восстановление религиозных институтов. Поэтому в самом начале фильма «Американцы из Джунгарии» следуют кадры буддийского молебна и комментарий: «Буддизм - это очень важный фактор в нашей жизни. Так было и так будет всегда».

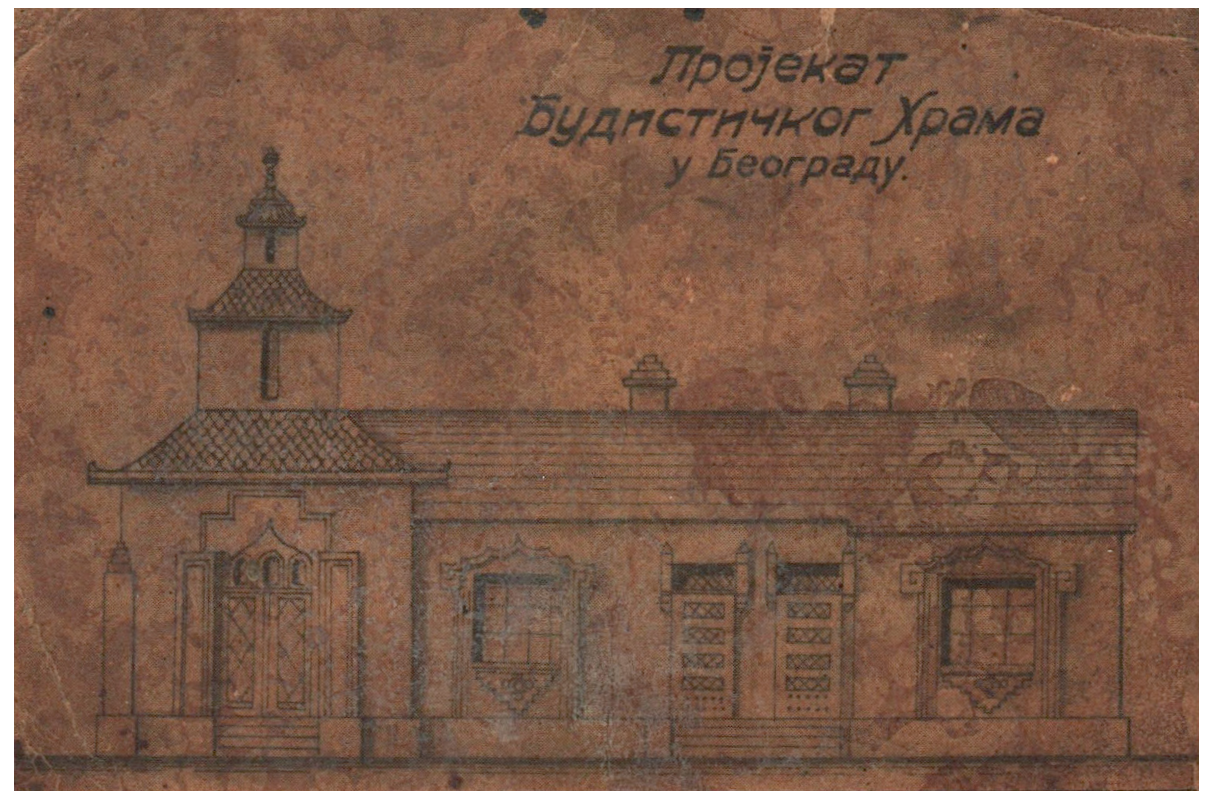

Фото 3. Проект первого буддийского храма в г. Белграде, построенного калмыками в 1928-1929 г2. Из архива семьи французских калмыков Зольвановых

(хранится в Научном архиве Калмыцкого научного центра РАН $)^{3}$.

Photo 3. A design for the first Buddhist temple in Belgrade, built by Kalmyks in 1928-1929.

Photo from Zolvanoff's family archive (preserved at the archive of the Kalmyk Scientific Center, RAS).

\footnotetext{
${ }^{1}$ Серенко, А. (2015) Американских калмыков потянуло к родной культуре [Электронный ресурс] // Независимая газета. 30.07. URL: http://www.ng.ru/regions/2015-07-30/5_kalmyk.html (дата обращения 15.02.2019).

${ }^{2}$ В 1955 г. в США прибыл геше Вангьял, в миру Боота Лиджиев (15.10.1901-30.01.1983), уроженец Калмыкии, чей вклад в становление буддийской традиции в США значителен (Хопкинс, 2009; Турман, 2009; Калмыцкий геше Нгаванг Вангьял. В Москве состоится презентация документального фильма «Калмыцкий геше Нгаванг Вангьял» (2018) [Электронный ресурс] // Сохраним Тибет! Дата публикации 23.03.2018. http://savetibet.ru/2018/03/23/geshe wangyal.html (дата обращения 15.05.2019)).

${ }^{3}$ Фотографии из архива семьи Зольвановых публикуются впервые. Автор статьи и руководство Калмыцкого научного центра РАН выражают глубокую признательность всем членам семьи Зольвановых, принявшим решение о передаче документов на хранение в Калмыкию, а также преподавателю Университета Тулузы - Жан Жорес (г. Тулуза, Франция) Дани Савелли и госпоже Жаклин Шасселю, благодаря которым уникальные документы, свидетельствующие о жизни калмыцкой диаспоры во Франции, были переданы в научный архив нашего учреждения.
} 


\section{НОВЫЕ ИССЛЕДОВАНИЯ ТУВЫ}

www.nit.tuva.asia

С калмыками в США прибыло 20 монахов почтенного возраста, которые подчинялись указаниям ${ }^{1}$ монгольского Дилова-хутухты (Rubel, 1967: 110). Благодаря подготовке послушников и прибытию из Индии от Далай-ламы монахов (среди которых был и геше Вангъял (Rubel, 1967: 110)) община укрепилась.

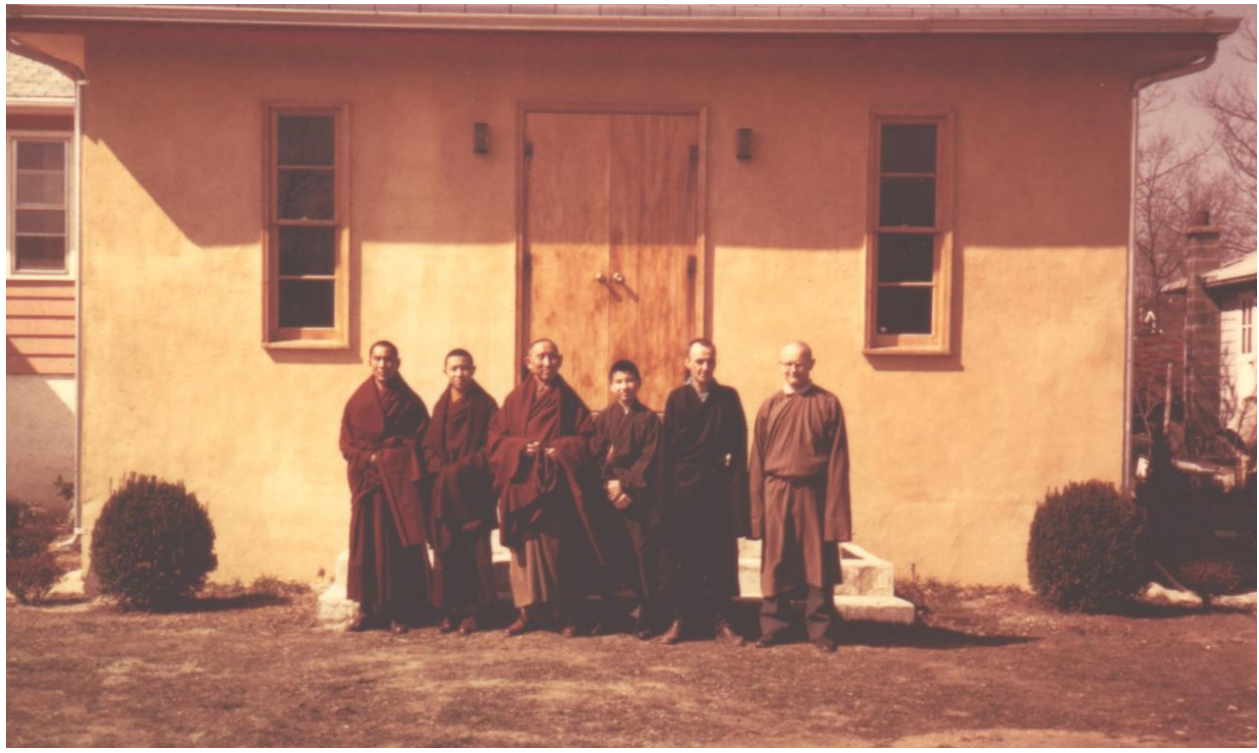

Фото 4. Геше Вангъял с монахами и учениками у здания Ламаистского буддийского монастыря Америки (ЛБМА) Лабсум Шедруб Линг², основанного им в 1958 г. Из архива семьи французских калмыков Зольвановых (хранится в Научном архиве Калмыциого научного центтра РАН).

Photo 4. Geshe Wangyal with monks and his disciples near the Lamaist Buddhist monastery of America (LBMA) Labrum Shedrup Ling, founded in 1958. Photo from Zolvanoff's family archive (preserved at the archive of the Kalmyk Scientific Center, RAS).

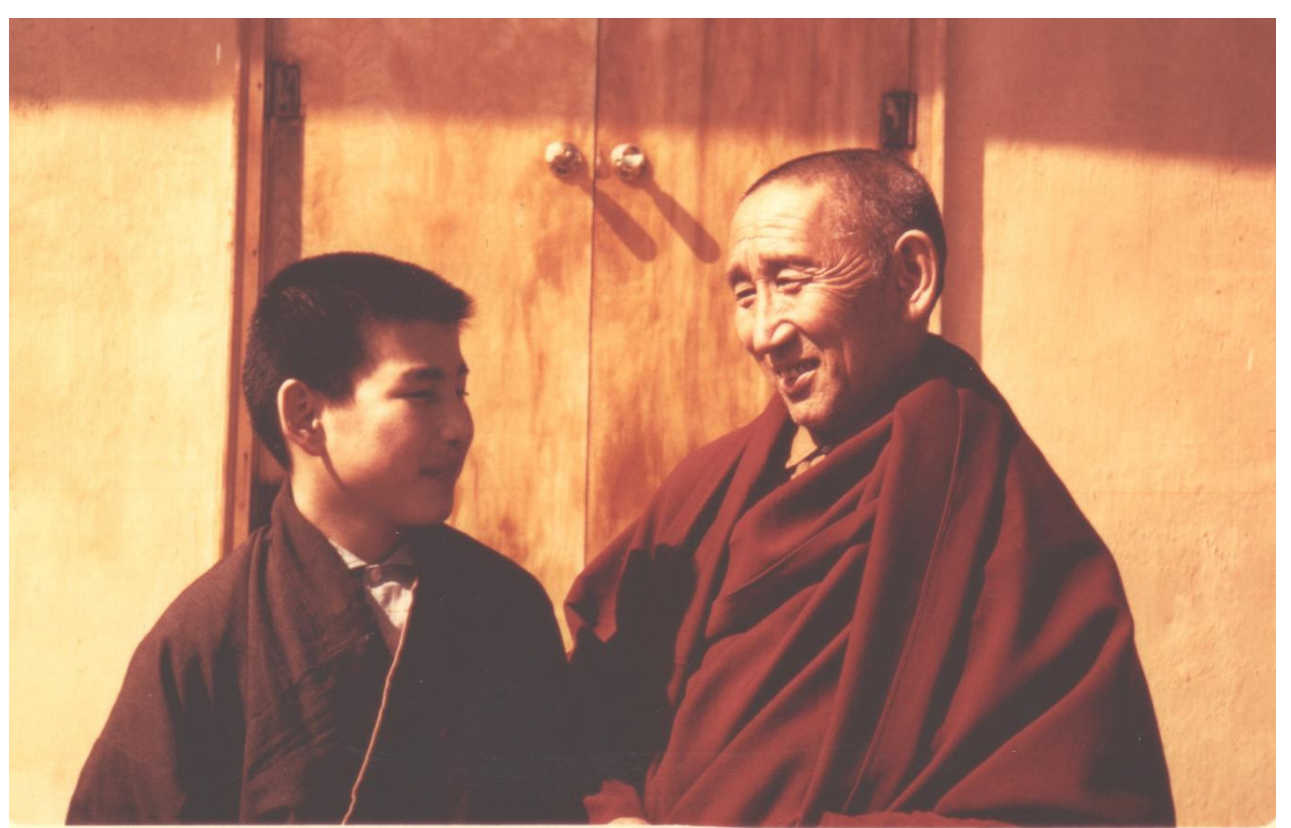

Фото 5. Геше Вангъял с учеником-калмыком у входа в Ламаистский буддийский монастырь Америки (ЛБмА) Лабсум Шедруб Линг, основанный им в 1958 г. Из архива семьи французских калмыков Зольвановых (хранится в Научном архиве Калмыцкого научного центра РАН).

Photo 5. Geshe Wangyal with his Kalmyk disciple near the Lamaist Buddhist monastery of America (LBMA) Labrum Shedrup Ling, founded in 1958. Photo from Zolvanoff's family archive (preserved at the archive of the Kalmyk Scientific Center, RAS).

${ }^{1}$ Среди калмыков-эмигрантов были попытки избрать верховного ламу; многие считали калмыком Дилова-хутухту (1884-1965) (Гучинова, 2004: 156), подробнее о котором см.: (Дилова-хутухта Монголии ..., 2018).

${ }^{2}$ Монастырь находился в Фармингдале, Нью Джерси. 
Субэтнический состав прибывших калмыков повлиял на формирование отдельных общин внутри калмыцкой общины и соответственно открытие не одного, а нескольких храмов.

В настоящее время среди калмыков США действуют такие храмы и общины:

1. Буддийский храм Раши Гемпил Линг ${ }^{1}$ (47 East 5th Street, Howell) был первым храмом, который открыли калмыки в США 3 ноября 1952 г. в переоборудованном гараже, о чем писала «New York Times» 24 ноября этого года (Хопкинс, 2009: 25). Столь скорое открытие храма являлось для общины настоятельной необходимостью. Название ему дано в память хурулу, где ранее служили его монахи Молом багши, Шар эмчи.

Вскоре было решено построить новый храм. Но калмыки США, являвшиеся представителями раз-

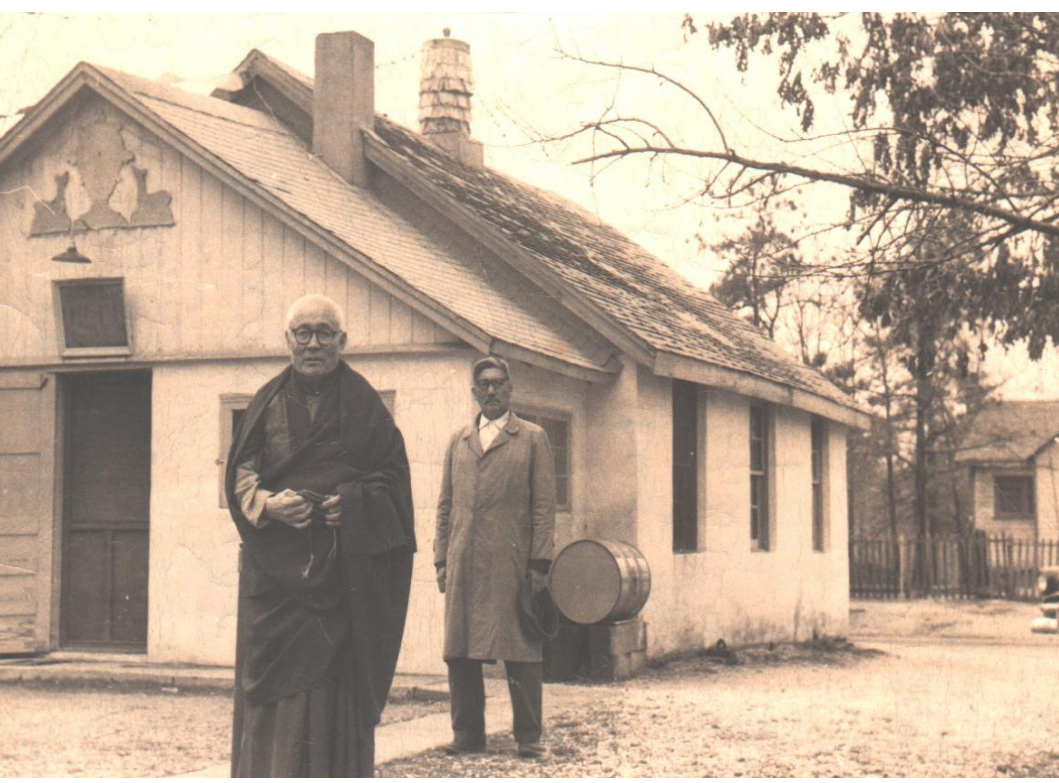

Фото 6. Шар эмчи и американский калмык Дорджи Пюрвеев у первого буддийского рама, открытого калмыками в США, - хурула Раши Гемпил Линг (г. Хауэлл, 1956²). Из архива семьи французских калмыков Зольвановых (хранится в Научном архиве Калмыцкого научного центра РАН).

Photo 6. Shar Emchi and American Kalmyk Dordzhi Pyurveev near the first Kalmyk Buddhist temple in USA - khurul Rashi Gempil Ling (Howell, 1956).

Photo from Zolvanoff's family archive (preserved at the archive of the Kalmyk Scientific Center, RAS).

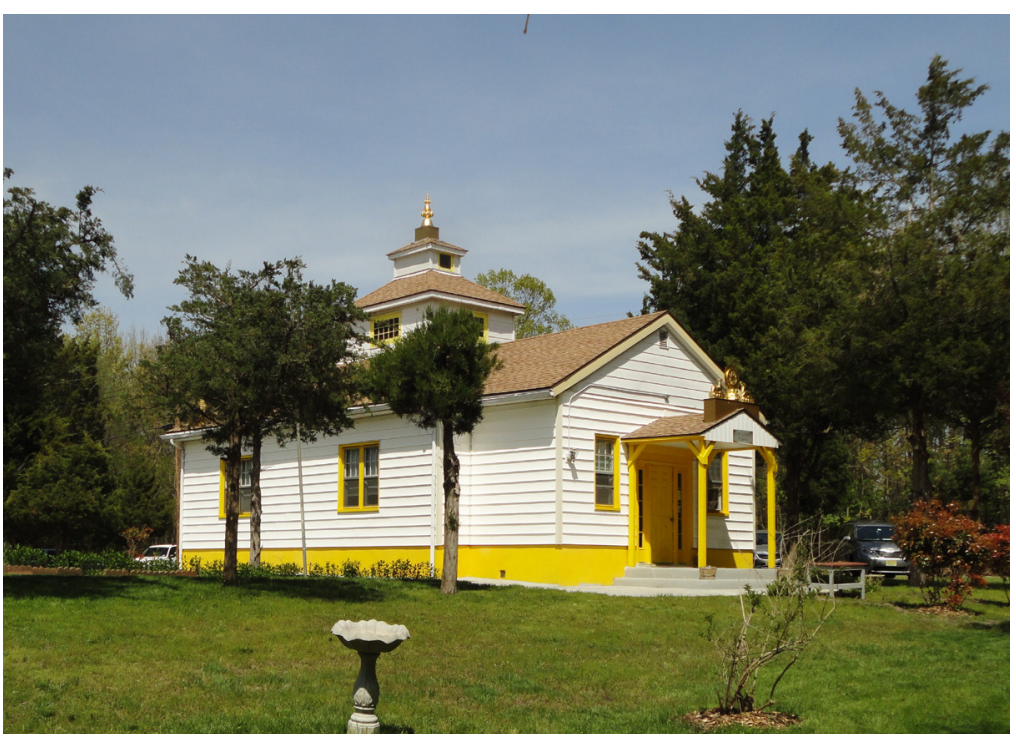

Фото 7. Калмыцзкий буддийский храм Таши Лумпо (Барун-хурул). Фото Э. Сангаджиева. 20112.

Photo 7. Kalmyk Buddhist temple Tashi Lumpo (Barun-khurul). Photo by E. Sangadzhiev. 2011. строительством сразу двух храмов. Новый хурул Раши Гемпил Линг был построен к 1958 г.

2. Буддийский храм Таши Лумпо (12 Kalmuk Rd., Howell) ${ }^{3}$ также называют Барун хурул или Олна газар (по П. Рубел - 'священная земля', см.: (Rubel, 1967), букв. значение - 'народное место' - отражает социальную роль хурула). Калмыки-бузава Хауэлла в 1953 г. приобрели землю, в 1954 г. начали строительство и уже 9 ноября 1955 г. освятили хурул Таши Лумпо, который, по данным Э.-Б. Гучиновой, является одним из самых посещаемых (Гучинова, 2004: 257-258). А. Борманжинов начинает с этой даты перечисление открытых калмыками храмов (Bormanzhinov, 1987: 6).

3. Буддийский храм Чойпэл Линг ${ }^{4}$ (186 West 6th Street, Howell) открыт в январе 1977 г. Здесь находятся троны

\footnotetext{
${ }^{1}$ http://www.rashigempilling.com/; www.facebook.com/pages/Rashi-Gempil-Ling-1St/162843447166585 (дата обращения 15.04.2019).

${ }^{2}$ Фото датируем исходя из даты записи - 1 января 1957 г. - на его обороте, сделанной Д. Пюрвеевым для племянника Дармы.

${ }^{3}$ https://www.youtube.com/channel/UCAKvBOr7wpX3QZCXwUbVsEw; https://www.facebook.com/TashiLhunpoUSA/ (дата обращения 15.04.2019).

${ }^{4}$ https://www.youtube.com/watch?v=xbvzTNRHd5E \&feature=youtu.be; http://www.nitsantemple.org/?fbclid=IwAR2tGxOPmtNSFI1DMsPy3QXkkOJ5WTMeGCtZfsVxzgjrKGVWIM0eOVCXjM; www.facebook.com/Nitsan-Choephel-Ling-Buddhist-Temple367629356664892 / (дата обращения 15.04.2019).
} 
Далай-ламы и Дилова хутухты, на почетном месте - фото Тэло Тулку Ринпоче (Э. Омбадыкова). Храм также называют «новый храм Раши Гемпил Линг» или Ницян (калм. Ниицән) хурул, так как он связан с этим калмыцким обществом. До недавнего времени в хуруле Ницян служили два старых монахамонгола - «старый маани ${ }^{1} »$ и «молодой маани»², здесь сохраняются калмыцкие обычаи, и молодые монахи, прибывшие из Тибета, знают про особенности обрядовой жизни калмыков.

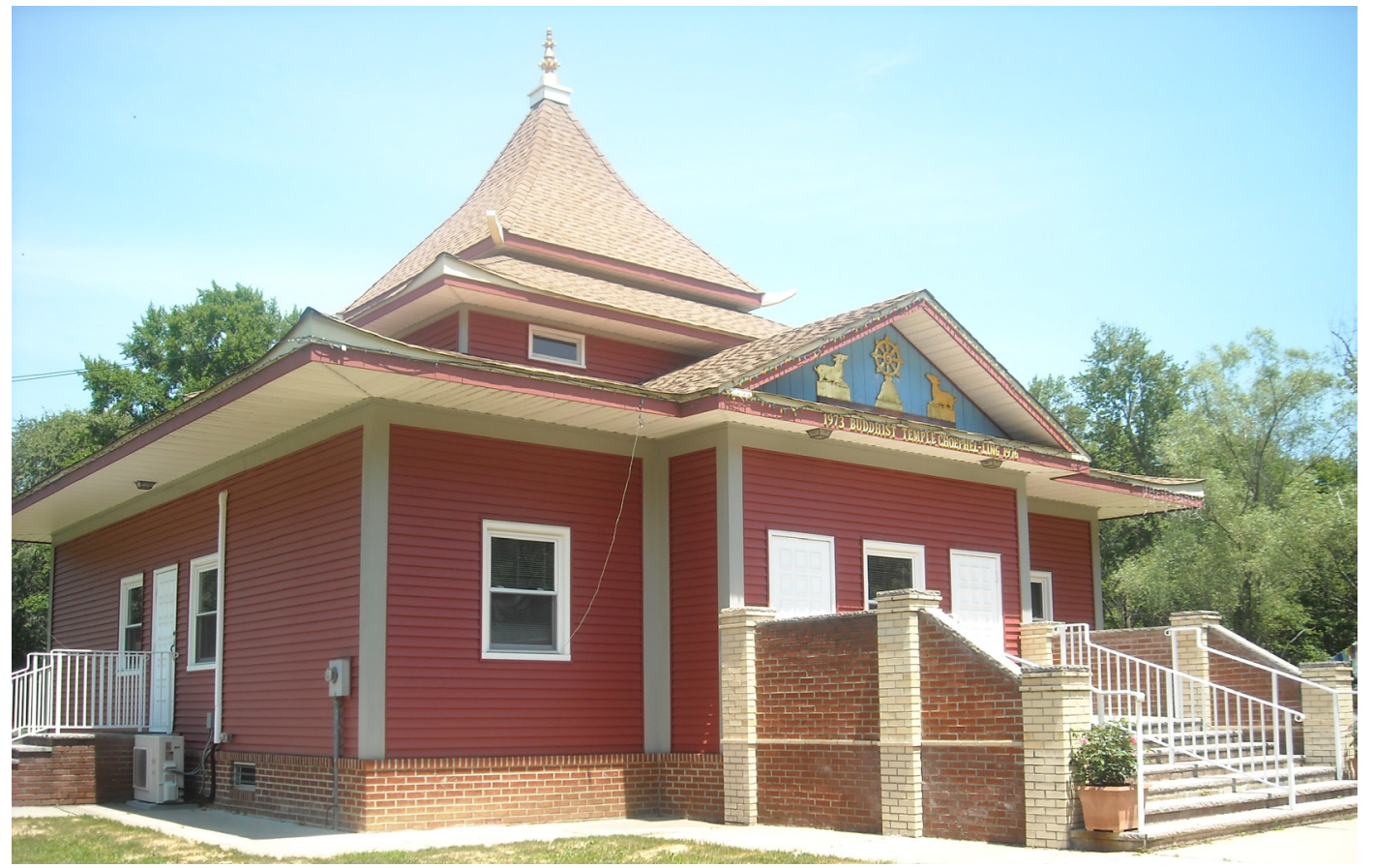

Фото 8. Калмыцкий буддийский храм Чойпэл Линг (Ницян-хурул). Фото автора, 2012 г.

Photo 8. Choephel Ling Kalmyk Buddhist Temple (Nitsan-khurul). Photo by the author, 2012.

4. В г. Филадельфии Калмыцкий буддийский храм Цзонхавы ${ }^{3}$ (29 East Courtland St., Philadelphia), сначала открытый в небольшом домике, был построен в 1984 г. Община донских калмыков «Kalmyk Brotherhood Society at the Temple of Saint Zonkava (KBS)» ('Общество Калмыцкого Братства храма святого Цзонхавы'), основавшая и построившая этот храм, основана в 1952 г. как организация калмыков, проживающих в районе Филадельфии и в округе; целью объявлена поддержка религии, культуры, традиций и будущего калмыков, особенно в Соединенных Штатах. При этом, как заявляется на официальном сайте организации, «Калмыцкое братство открыто для тех, кто искренне заинтересован в том, чтобы узнать больше о культуре или религии калмыцких монголов и поддержать наше продолжение в будущем»4.

В сообществе эмигрантов сохранились принципы формирования «приходов» и буддийских храмов, которые были характерными для калмыцкой степи до начала XX в. ${ }^{5}$ (Буддийская традиция, 2015: 22; Бакаева, 2018a). Связь между этническими группами калмыков и хурулами не могла не сказаться на формирующейся традиции среди эмигрантов в США, где она явилась наиболее значимым фактором сохранения этнической многоуровневой идентификации. Таким образом, в пространстве культуры американских калмыков прослеживается его членение, подобное членению пространства в буддийской культуре российских калмыков.

В буддийском культурном пространстве калмыков, проживающих в разных странах, есть также объединяющие символы и фигуры.

\footnotetext{
${ }^{1}$ Американские калмыки называют монахов «маани».

${ }^{2}$ В декабре 2014 г. Ендонжамц (Йонден Гьяцо) скончался в возрасте 94 лет; см.: https://www.youtube.com/watch?v=5kxJT3AtrJg (дата обращения 15.04.2019).

${ }^{3}$ https://kalmykbrotherhoodsociety.org/; www.facebook.com/groups/63988803184/; https://www.facebook.com/pages/Saint-Zonkava-Temple/195349440486101 (дата обращения 15.04.2019).

${ }^{4} \mathrm{https}: / /$ kalmykbrotherhoodsociety.org/

${ }^{5}$ См., например: Митиров, А. Г. (2004) Хурул воздвигается с тем, чтобы он навсегда остался достоянием общества // Хальмг үнн (газета). 21.10. № 219-220.
} 


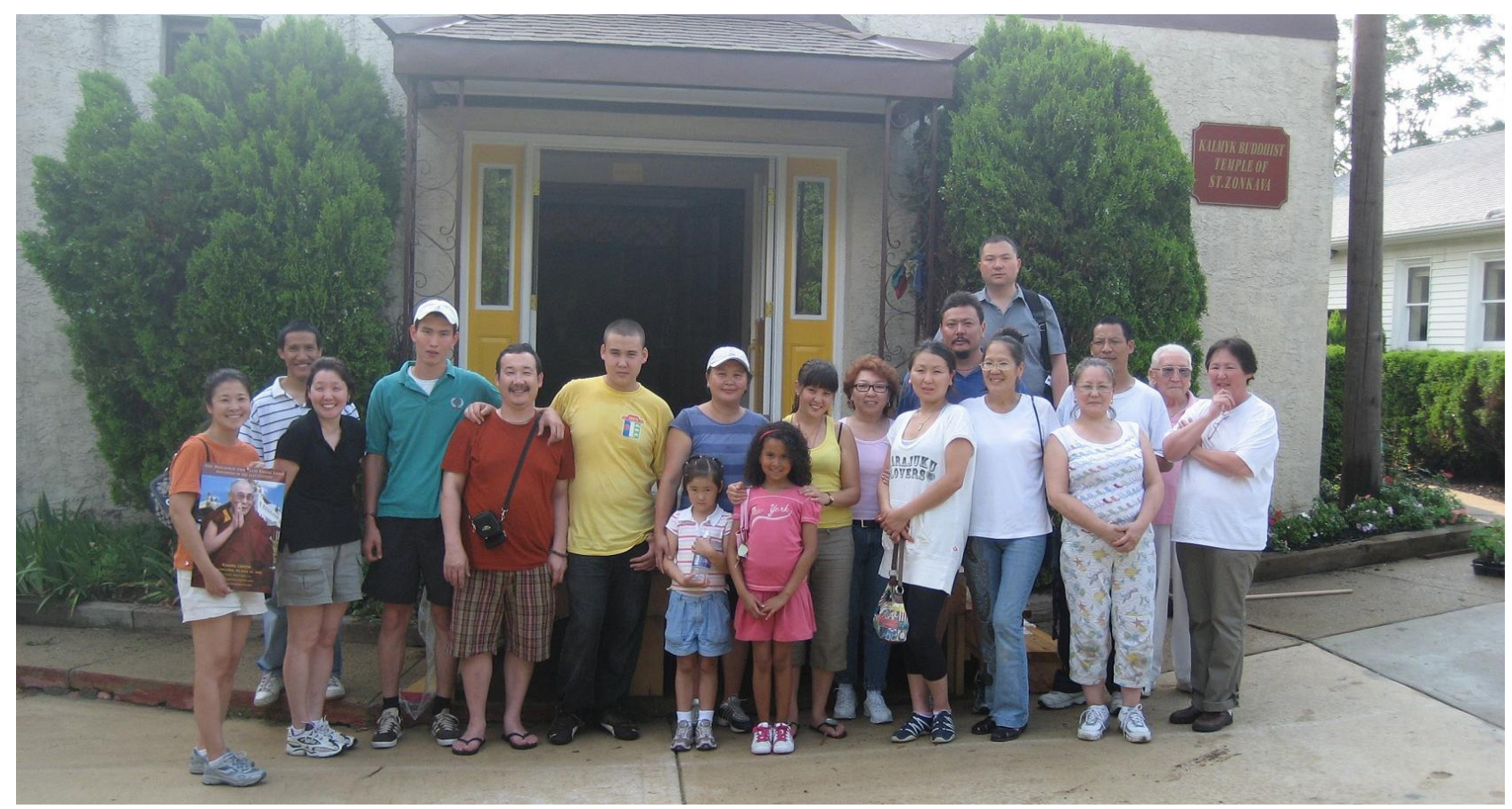

Фото 9. Тэло Тулку Ринпоче и группа калмыков у калмыцкого буддийского храма в Филадельфии. Фото Э. Сангаджиева, 2011 г.

Photo 9. Telo Tulku Rinpoche and a group of Kalmyks at the Kalmyk Buddhist temple in Philadelphia. Photo by E. Sangadzhiev, 2011.

Особая роль принадлежит образу божества Белый старец, почитаемого как покровитель всех калмыков. Зафиксирован факт адаптации буддийского текста для проведения калмыками США обрядов почитания Белого старца: настоятель храма в Филадельфии С.-Р. Меньков в рукописи «Сутра, именуемая „Способная усмирить и подавить землю и воду под названием Сашива ${ }^{1 “ », ~ с о з д а н н о и ̆ ~ в ~ С Ш А, ~ в в о д и т ~ в ~}$ текст сутры название страны, чтобы эта земля в результате чтения текста и проведения обрядов также оказалась под покровительством Белого старца.

Объединяет буддистов двух стран Тэло Тулку Ринпоче - Верховный лама Калмыкии, который также является лидером калмыков-буддистов США и перерожденцем Дилова-хутухты, которого почитали и которому подчинялись члены калмыцкой общины США.

Пример калмыцкой группы иммигрантов подтверждает выводы исследователей социологии религии в США (Herberg, 1960; Hirshman, 2004; Каргина, 2014 и др.) и демонстрирует, что переживающая травму межконтинентальной миграции группа находила в религиозной жизни, во-первых, убежище, во-вторых, статус, и, в-третьих, ресурс в повседневной жизни (Hirshman, 2004: 1228). Создание нескольких калмыцких буддийских храмов и общин при них являлось не только проявлением субэтнической идентичности и борьбы за лидерство в группе прибывших в США калмыков в общине, но и стремлением разных групп мигрантов утвердиться в новых условиях, получить возможность «создать параллельный набор социальных институтов», найти пути для социального продвижения в группе, лидерства, а также обеспечения общественных работ. Иначе говоря, в культурном пространстве принимающего общества в условиях религиозного плюрализма сообщество мигрантов создает свой сектор, свое культурное пространство, являющееся убежищем, источником статусности и ресурсов для новых мигрантов - и связанное с культурным пространством своего этноса. Хотя в быту представления о более высоком статусе мигрантов первой волны сохранялись до конца XX в. (Четырова, 2010: 332), наличие буддийского храма у каждой группы калмыков-эмигрантов уравнивало в статусе их общины. Вывод о религиозных общинах как способе продвижения и воспитания лидеров подтверждается и программным тезисом Kalmyk Youth Coalition: деятельность по распространению культуры есть одновременно и ресурс для воспитания лидеров.

Буддизм остается значимым фактором и для калмыков-эмигрантов новой волны. В 1990-е гг. наличие ряда буддийских храмов у калмыцкой общины США для них было явлением удивительным

\footnotetext{
${ }^{1}$ «Слово Sašiva (Сашива) - это <...> искаженная <...> форма от русской аббревиатуры США <..>, т. е. аббревиатуры сокращенного названия страны, в которой в результате эмиграции оказались последователи буддийского учения - выходцы из Калмыкии» (Музраева, 2016: 306).
} 
(в Калмыкии первая буддийская община была зарегистрирована в 1988 г.). Но развитие религиозных институтов в Калмыкии происходило стремительно (Бакаева, 2004; 2018bc; Bakaeva, 2014 и др.); на территории каждого административного района (что примерно совпадает с расселением субэтнических групп в прошлом) стали появляться хурулы и другие культовые объекты. Возведение крупных храмов в столице Калмыкии - г. Элисте и целенаправленная работа по возрождению национальных традиций и духовности, а также новые возможности информационных технологий позволили администрации Центрального Калмыцкого хурула, открытого в г. Элисте в 2005 г., сделать его не только конфессиональным, но и культурным центром, а его сайт (http://khurul.ru) - источником знаний для калмыков, связанных с буддийской традицией.

Многие из новых мигрантов-калмыков расселяются в Нью Джерси или поблизости - это позволяет освоиться с меньшими усилиями в новом сообществе: вхождение в общину людей, принадлежащих к одной религиозной традиции, означает также нахождение в одном культурном пространстве и позволяет сохранить этническую идентичность, адаптируясь в принимающем сообществе. Эта тенденция характерна для иммигрантов США: «Церкви и храмы играют важную роль как сообщества по обмену информацией, которые расширяют социально-экономические возможности иммигрантов и их детей <...> Определенность религиозных заповедей может обеспечить якорь, поскольку иммигранты должны адаптироваться и изменить многие другие аспекты их жизни и привычек» (Hirshman, 2004: 1210-1211).

Конфессиональная культура включает разные аспекты, проявляющиеся в жизни общины. Для буддийской общины калмыков религиозная повседневность связана не только со знаниями в области буддийского учения, мифологии, фольклора и др., но и с сохранением таких элементов культуры, как приверженность традиционной обрядности, проведение национальных календарных праздников, соблюдение правил этикета (что особенно важно для сохранения памяти о традициях поведения ${ }^{1}$ ), знание о традиционной одежде (в наши дни верующие стараются использовать стилизованную одежду); а также внутриобщинных связей и возможности общения на родном языке. Это также является признаком расширения культурного пространства: в новой среде сохраняется социальная и культурная ниша, в которой воспроизводятся компоненты этнической культуры. Так, в национальные праздники калмыцкая община встречается в Хауэлле или Филадельфии, а теперь и в Нью-Йорке; отмечают и «День города», проводимый в Элисте в третью субботу сентября. Объявления, как правило, размещаются на сайтах буддийских храмов и общин, на страницах в социальных сетях (вход на мероприятия для детей и пожилых людей бесплатный, что нацелено на передачу межпоколенной традиции, средства, поступающие от представителей других возрастных категорий, расходуются на организацию праздников и поступают в фонд храмов) других от них.

Близость г. Хауэлла к Нью-Йорку, где появилась в последние 20 лет значительная группа калмыков, позволяет им при необходимости посещать буддийские калмыцкие хурулы. Мигранты новой волны больше посещают храмы Ницян и Раши Гемпил Линг (Гучинова, 2004: 259). Для представителей новых эмигрантов их внеобрядовая жизнь как буддистов связана прежде всего с религиозной повседневностью. Члены калмыцкой общины, в том числе проживающие в Нью-Йорке, принимают активное участие в мероприятиях, проводимых в храмах Хауэлла: с развитием компьютерных технологий информация о планах буддийских хурулов становится доступной широкому кругу людей. Они объединяются прежде всего на этническом, а не субэтническом уровне - ведь территории расселения новых мигрантов весьма различны, пространство, освоенное ими, не связано с субэтнической группой, как это было у первых поселенцев-калмыков в США, которые специально расселялись поблизости.

Объединяет этих новых мигрантов пространство культуры, в том числе и прежде всего пространство буддийской калмыцкой культуры. Этому способствует наличие групп и объединений - как реальных, так и виртуальных (в социальных сетях) (Kalmyk American Society²; Kalmyk Brotherhood Society; Kalmyk Mongolian Buddhist Center; Nitsan Choephel Ling Buddhist Temple; Rashi Gempl-ling. First Kalmuk Buddhist Temple; Rashi Gempl-ling1st; Tashi Lhunpo; Kalmyks in USA; Kalmyk Project (Kalmyks in New York); Kalmyk Youth Coalition; и др.). Калмыцкая община в США живет активной жизнью. На странице Kalmyk Project в Facebook обсуждаются не только информация о жизни калмыков США, но и актуальные моменты из жизни Республики Калмыкия. Вопросы развития буддийской культуры и истории монгольских народов также освещаются на сайте в и социальных сетях на страницах Тибето-монгольского буддийского

\footnotetext{
${ }^{1}$ Так, в храме Таши Лумпо в г.Хауэлле Э.-Б. Гучинова наблюдала соблюдение традиционного для калмыцкой кибитки гендерного деления пространства: правая часть молельного зала занималась мужчинами, левая - женщинами, и нарушение этого порядка случалось в крайних случаях (Гучинова, 2004: 258-259).

${ }^{2}$ www.kalmykamericansociety.org (дата обращения 15.04.2019).
} 
НОВЫЕ ИССЛЕДОВАНИЯ ТУВЫ

www.nit.tuva.asia
№3

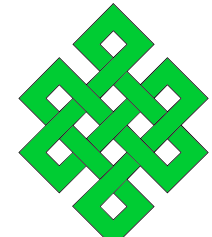

2019
THE NEW RESEARCH OF TUVA

Novye issledovaniia Tuvy

культурного центра и отчасти - Тибетского буддийского исследовательского центра (Tibetan Mongolian Buddhist Cultural Center ${ }^{1}$; Tibetan Buddhist Learning Center²).

Калмыцкая диаспора увеличивается, а интерес калмыков, проживающих в разных странах, к ее жизни, как и достижениям отдельных калмыков, велик. Одновременно познание опыта позволяет молодому поколению заинтересоваться возможными путями реализации своих амбициозных планов.

Идентичность людей, определяющих себя калмыками, за рубежом такая же многоуровневая, как и в родной республике. Но если представители первой волны называли себя часто ойратами или монголами (Rubel, $1967^{3}$ ), поскольку в США мало кто знал о калмыках, то представители новой волны эмигрантов акцентируют свою калмыцкую идентичность. Тем не менее, в условиях инокультурного окружения происходит сближение с представителями родственных культур. Примером может служить «Первая ойратско-монгольская конференция».

Наиболее значимым фактором идентичности в американской общине калмыков является осознание принадлежности к калмыцкому этносу и чувство связи с Республикой Калмыкия, а также чувство родства со своим родом, семьей, проживают ли ее представители в одной стране или на разных континентах. Поэтому символами идентичности выступают флаг Калмыкии, традиционный символ «улан зала» 'красная кисть' [на головных уборах], элементы национального костюма и кухни, а также знание языка, фольклора, традиций, в том числе и прежде всего - семейных, а также календарных праздников (Цаган сар, Зул, Урюс сар).

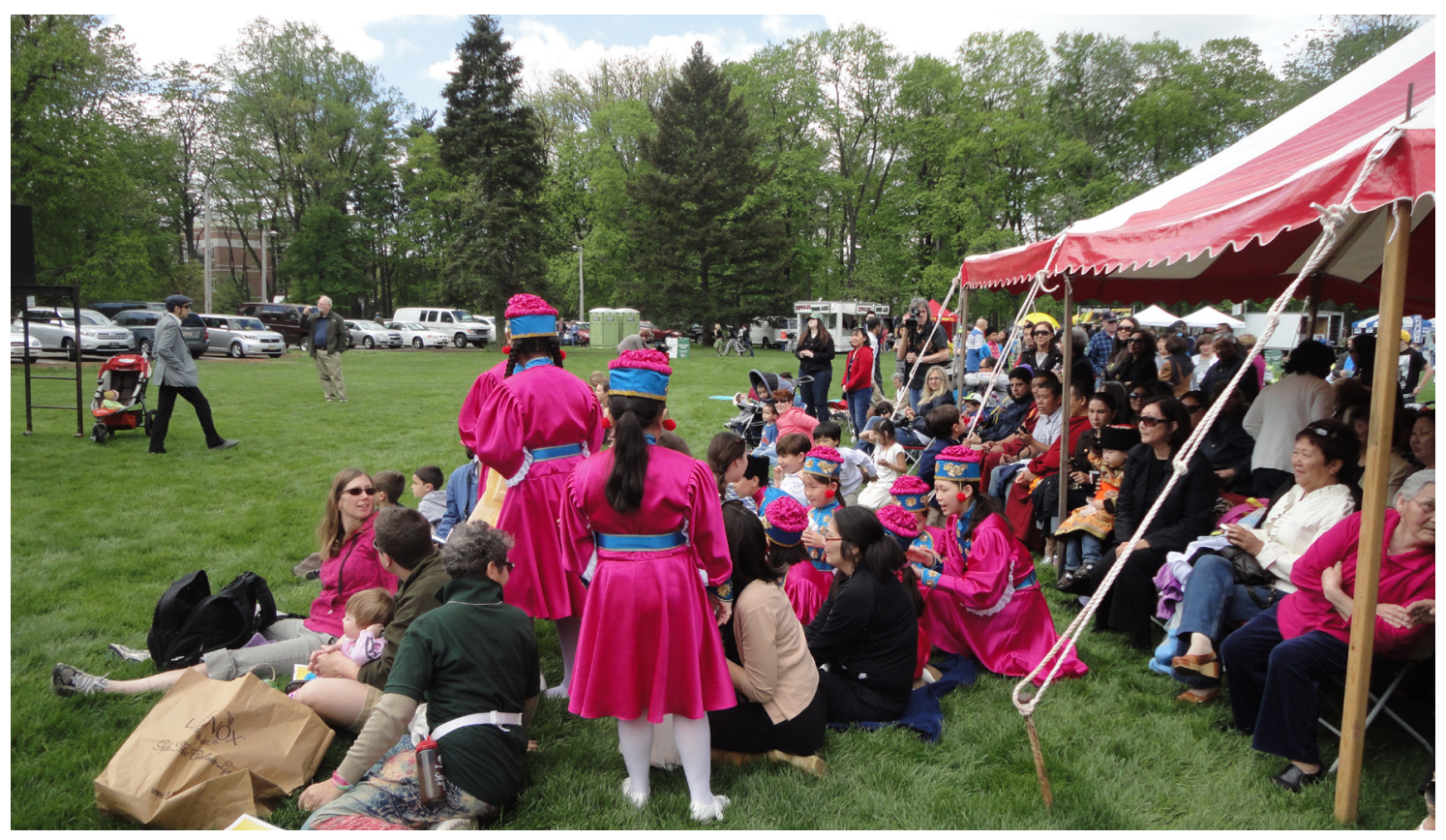

Фото 10. Фольклорный фестиваль в Нью-Джерси. Фото Э. Сангаджиева, 2011 г. Photo 10. Folklore Festival in New Jersey. Photo by E. Sangadzhiyev, 2011.

\section{Заключение}

Уникальность истории первых калмыцких общин в США заключается в сохранении их представителями религиозных традиций, которые являлись весьма значимыми в Калмыкии до периода «наступления на религию» в 1930-е гг. Адаптация иммигрантов в принимающем обществе со-

\footnotetext{
${ }^{1}$ https://www.tmbcc.org/ (дата обращения 15.04.2019).

${ }^{2}$ http://www.labsum.org/history.html (дата обращения 15.04.2019).

${ }^{3}$ См. также: Тэло Тулку Ринпоче о визите в Монголию (2009) [Электронный ресурс] // Калмыцкий Центральный Буддийский монастырь "Геден Шеддуп Чой Корлинг". URL: http://khurul.ru/2009/09/telo-tulku-rinpoche-o-vizite-v-mongoliyu/ (дата обращения 15.05.2019).

${ }^{4}$ Надбитова И. Тэло Тулку Ринпоче встретился с калмыками культурно-религиозного центра «Kalmyk Project» в Нью-Йорке (дата публикации 20.02.2013) [Электронный ресурс] // Калмыцкий Центральный Буддийский монастырь "Геден Шеддуп Чой Корлинг". URL: www.khurul.ru/2013/02/telo-tulku-rinpoche-vstretilsya-s-kalmykami-kulturno-religioznogo-centra-kalmyk-project-v-nyu-jorke/ (дата обращения 15.04.2019).
} 
провождалась формированием общин на основе традиций, с учетом субэтнической принадлежности, что являлось главным принципом формирования хурулов при родовых группах калмыков в прошлом.

Этническая и субэтническая идентичность сохранялись в калмыцкой общине за счет планомерной работы ее лидеров по сохранению культуры и прежде всего и благодаря религиозной составляющей. При этом буддийские храмы выполняли и роль общественных центров: в них концентрировалась и религиозная, и светская жизнь членов общин.

Процессы глобализации активизировали миграционные процессы во всем мире. Как считают представители калмыцких общин, недавнее вливание иммигрантов за последние 20 лет помогло им оставаться активными и энергичными, и в этом процессе большую роль сыграли новые технологии информационного характера, социальные сети, позволяющие налаживать контакты и распространять информацию (Hochron, Staff, 2012: Электр. ресурс).

Буддийская религия, имевшая глубокое влияние в обществе в период начала ХХ в., явилась стержнем культуры, сохранить которую намеревались калмыки-эмигранты. Буддийская идентичность объединяет единое пространство конфессии, в котором объединяются калмыки и обращаются к ойратскому миру. В культурном пространстве калмыцкой общины, как и прежде, наиболее значимым фактором является буддизм, последователи которого объединяются вокруг лидера всех буддистов Далай-ламы XIV. Личность, объединяющая разные анклавы калмыцкого народа и обладающая несомненным авторитетом в буддийском и монгольском мире - Тэло Тулку Ринпоче ${ }^{1}$ (Болдуринова, 2015 и др.), перерожденец Дилова хурухты, который в США был связан с калмыками.

Миграции не только способствовали сохранению идентичности калмыцкой общины США, но и дали новый толчок и всплеск развитию и расширению культурного пространства, которое проявляется в использовании несколькихязыков; привлечениипредставителей родственныхнародов к мероприятиям калмыков в США; активизации общественной жизни, проведении регулярных собраний (от Первой ойратской конференции, конференций калмыцкой молодежи, проведения национальных праздников Зул и Цаган сар до уроков танцев, шитья платьев и т. п.). Другим толчком в активизации культурной жизни калмыков США явилось приглашение калмыцких профессиональных артистов (ряд мигрантов ранее работали в сфере культуры), певцов, джангарчи на фольклорные фестивали и участие опытных организаторов в мероприятиях общины².

Современные технологии расширяют пространство внутри американской общины калмыков, где социальные сети, мобильная связь и ее приложения позволяют наладить оперативный обмен информацией, согласованно участвовать в мероприятиях в Филадельфии и Хауэлле (хотя Бруклин становится еще одним центром).

...«Маленькая Калмыкия в Нью Джерси» - так назвал свою статью А. Мельников, задавшись вопросом: «...Почему конференция калмыцкой молодежи, целью которой объявлено приобщение калмыков России и мира к национальной культуре и буддизму, состоялась в США, а не в Калмыкии?»³. Эти слова перекликаются со словами молодой калмычки: «Бруклин - маленькая Элиста». «Бруклинград» так назван один из репортажей о калмыцком землячестве в Нью Йорке, которое состоялось в день города Элисты для совместного празднования этой даты ${ }^{4}$. Оказавшись на другом краю света, калмыки прилагают все усилия по сохранению культуры своего народа, тем самым расширяя пространство своей культуры. Для мигрантов новой волны Элиста и Калмыкия остаются домом, именно потому связи с Домом остаются очень тесными, что возможно благодаря новым информационным технологиям.

\footnotetext{
${ }^{1}$ All-American Lama: How an 11th Century Mystic Was Reborn in Philadelphia (2012) [Электронный ресурс] // Time. URL: http:// content.time.com/time/world/article/0,8599,2111552-1,00.html (дата обращения 15.04.2019).

${ }^{2}$ https://www.youtube.com/watch?v=Pi_iMO7V5Fk; https://www.youtube.com/watch?v=NL1w962W3Fg; https://www.youtube.com/ watch?v=mUtxhTnnCNA; https://www.youtube.com/watch?v=kTkrXuqYQwQ; https://www.youtube.com/watch?v=GOatlQSr4Hw; http://asiarussia.ru/news/17445/; https://www.youtube.com/watch?v=z2gjTvVZ9Bw (дата обращения 15.04.2019).

${ }^{3}$ Мельников,А.(2015) Маленькая Калмыкия в Нью-Джерси. Верховныйлама ответил на вопросы об американской конференции молодых эмигрантов [Электронный ресурс] // Независимая газета. 05.08. URL: http://www.ng.ru/ng_religii/2015-08-05/3_jersey. $\mathrm{html}$ (дата обращения 15.12.2018).

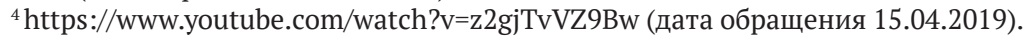




\section{СПИСОК ЛИТЕРАТУРЫ}

Антошин, А. В. (2005) Через «железный занавес»: контакты российских эмигрантов с гражданами СССР в середине 1940-х - середине 1960-х годов // Известия Уральского государственного университета. Проблемы образования, науки и культуры. Вып. 18. С. 129-141.

Бакаева, Э. П. (2004) О современной религиозной ситуации в Калмыкии (буддизм и «посвященные») // Этнографическое обозрение. № 3. С. 23-39.

Бакаева, Э. П. (2018а) Вопросы этнической идентификации в документах калмыцких буддистов первой трети XX в. в контексте современных проблем исследования этнической истории калмыков // Oriental Studies. № 4. C. 52-67. DOI:10.22162/2619-0990-2018-38-4-52-67.

Бакаева, Э. П. (2018b) Калмыцкие буддисты и Далай-лама XIV: страницы истории Калмыкии 1992 года // Новый исторический вестник. № 3. С. 111-122. DOI: 10.24411/2072-9286-2018-00026

Бакаева, Э.П.(2018c) Первая конференция буддистов Калмыкии и Астраханской области: Предыстория и решения (1988-1991 годы) // Новый исторический вестник. № 1. С. 71-80. DOI: 10.24411/2072-92862018-00004

Баранова, В. В. (2016) Невидимая миграция: путешествие из Калмыкии в Москву // Вестник Калмыцкого института гуманитарных исследований РАН. № 2. С. 89-97.

Буддийская традиция в Калмыкии и Западной Монголии. Сакральные объекты (2015) / Бакаева Э. П., Орлова К. В., Н. Хишигт, Ц. Энхчимэг. М. : Наука, Восточная литература. 238 с.

Гучинова, Э.-Б. М. (2004) Улица Kalmuk road. История, культура и идентичности калмыцкой общины в США. СПб. : Алетейя. 340 с.

Дилова-хутухта Монголии. Политические мемуары и автобиография перевоплощения буддийского ламы (2018) / пер. с англ. Е. В. Гордиенко; отв. ред. рус. издания С. Л. Кузьмин и Ж. Оюунчимэг, лит. редактор рус. издания Н. Г. Иноземцева. М. : Фонд «Сохраним Тибет». 352 с., 11 илл.

Дорджиев, В. П. (2000) Дело всей жизни. Ставрополь: Ставроп. краевая тип. 155 с.

Жуковская, Н. Л. (1988) Категории и символика традиционной культуры монголов. М. : Наука. 194 с.

Иванов, О. И. (2015) Культурное пространство как пространство паттернов поведения и мышления // Труды Санкт-Петербургского государственного института культуры. Т. 206. С. 19-26.

Каргина, И. Г. (2014) Религия как фактор адаптации иммигрантов: особенности американского случая // Полис. Политические исследования. № 2. С. 164-174.

Лотман, Ю. М. (1999) Внутри мыслящих миров: Человек-текст-семиосфера-история. М. : Языки русской культуры. 458 с.

Малькова, В. К., Тишков, В. А. (2009) Культура и пространство. Книга первая. Образы российских республик в Интернете. М. : ИЭА РАН. 150 с.

Малькова, В. К., Тишков, В. А. (2010) Культура и пространство. Книга вторая. Историко-культурные бренды территорий, регионов и мест. М.: ИЭА РАН. 182 с.

Миленкович, Т. (1998) Калмици у Србији. 1920-1944. Београд: Тraco. 246 с. (На сербск. яз.).

Музраева, Д. Н. (2016) Тексты Белого старца у ойратов и калмыков // Трансграничная культура: очерки сравнительно-сопоставительного исследования традиций западных монголов и калмыков / Э. П. Бакаева, К. В. Орлова, Д. Н. Музраева и др. Элиста: КалмНЦ РАН. 456 с. С. 294-312.

Намруева, Л. В. (2011) Влияние миграции молодежи на сохранение этничности (на примере калмыков) // Вестник Российского университета дружбы народов. Серия: Социология. № 2. С. 87-92.

Намруева, Л. В. (2013) Миграционные установки молодежи Калмыкии (по материалам исследования) // Вестник Калмыцкого университета. № 2. С. 64-70.

Наминов-Бурхинов, Д. (1997) Борьба за гражданские права калмыцкого народа. Элиста : АПП «Джангар». 181 с.

Орлова Е. В. (2010) Культурное пространство: определение, специфика, структура // Аналитика культурологии. № 3 (18). С. 42-53.

Тишков, В.А. (2003) Культурный смысл пространства //V Конгресс этнографов и антропологов России. Омск, 9-12 июня 2003 г. Тезисы докладов / отв. ред. В. А. Тишков. М.: ИЭА РАН. 380 с. С. 16-24.

Топалова, Д. Ю. (2017) Об истории возникновения калмыцкого зарубежья (20-30-е гг. XX в.) // Вестник Калмыцкого института гуманитарных исследований РАН (Oriental Studies). № 5. C. 237-249. DOI: 10.22162/2075-7794-2017-33-5-237-249 
Топалова, Д. Ю. (2019). Общественно-культурная деятельность калмыцкой эмиграции (1920-е начало 1930 гг.) // Oriental Studies. № 2. C. 195-206. DOI: 10.22162/2619- 0990-2019-42-2-195-206

Турман, Р. (2009) Раздумья о жизни досточтимого дрепунгского геше Наванга Вангьяла, выходца из Цаган Булукха в Калмыкии // Буддизм в России. № 42. С. 59-62.

Убушаев, М. Б. (2009) Миграционные процессы в Республике Калмыкия в постсоветский период // Вестник Калмыцкого института гуманитарных исследований РАН. № 1. С. 65-69.

Ханинова, Р. М. (2008) Давид Кугультинов и Михаил Хонинов: диалог поэтов. Элиста : Издательство Калмыцкого университета. 185 с.

Хопкинс, Дж. (2009) Калмыцкий вклад в развитие буддизма на Западе // Буддизм в России. № 42. C. 25-27.

Четырова, Л.Б. (2010) Калмыки: между Востоком и Западом //Евразийский мир: ценности, константы, самоорганизация / под ред. Ю. В. Попкова. Новосибирск: Нонпарель. 449 с. С. 292-352.

Aubin, F. (1968) Une société d'émigrée: la colonie des kalmouks en France // L’Année sociologique. 3-eme serie. Vol.17/1966. P. 133-212.

Bakaeva, E. (2014) Research on the History of Buddhism in Kalmykia at the Present Stage // Anthropology \& Archeology of Eurasia.Vol. 53. Is. 4. P. 21-46.

Bormanzhimov, A. (1987) The Kalmyks in the United States 35 Years After. Howell, NJ: Kalmyk Society in the United States. $17 \mathrm{p}$.

Herberg, W. (1960) Protestant, Catholic, Jew: An Essay in American Religious Sociology. New York : Anchor Books. 309 p.

Hirschman, Ch. (2004) The Role of Religion in the Origins and Adaptation of Immigrant Groups in the United States // International Migration Review. Vol. 38. Iss. 3. P. 1206-1233.

Hochron, A., Staff, P. (2012) Buddhist Community Has Deep Roots in Howell. Temples help bring tight knit community together [Электронный ресурс] // Patch 18.05. URL: https://patch.com/new-jersey/howell/buddhist-community-has-deep-roots-in-howell (дата обращения 05.05.2019).

Rubel, P. G. (1967) The Kalmyk Mongols: a study in continuity and change. (Indiana University Publications. Uralic and Altaic Series, Vol. 64). Bloomington: Indiana University; The Hague: Mouton and Co. XIV. 282 p.

Дата поступления: 03.06.2019 г.

\section{REFERENCES}

Antoshin, A.V. (2005) Cherez «zheleznyi zanaves»: kontakty rossiiskikh emigrantov s grazhdanami SSSR v seredine 1940-kh - seredine 1960-kh godov [Through the Iron Curtain: contacts of Russian émigrés with citizens of the USSR between the mid-1940s and mid-1960s]. Izvestiya Ural'skogo gosudarstvennogo universiteta. Problemy obrazovaniya, nauki i kul'tury, no. 18, pp. 129-141. (In Russ.).

Bakaeva, E. P. (2004) O sovremennoi religioznoi situatsii v Kalmykii (buddizm i «posvyashchennye») [On the contemporary religious situation in Kalmykia (Buddhism and the 'initiates')]. Etnograficheskoe obozrenie, no. 3, pp. 23-39. (In Russ.).

Bakaeva, E. P. (2018a) Voprosy etnicheskoi identifikatsii v dokumentakh kalmytskikh buddistov pervoi treti XX v. v kontekste sovremennykh problem issledovaniya etnicheskoi istorii kalmykov [Ethnic identity issues of Kalmyk Buddhists in the 1900-1930s: a perspective from the current challenges of Kalmyk ethnic history studies]. Oriental Studies, no. 4, pp. 52-67. (In Russ.). DOI: 10.22162/2619-0990-2018-38-4-52-67

Bakaeva, E. P. (2018b) Kalmytskie buddisty i Dalai-lama XIV: stranitsy istorii Kalmykii 1992 goda [The Kalmyk Buddhists and the Fourteenth Dalai Lama: Pages from the History of Kalmykia (1992)]. Novyi istoricheskii vestnik, no 3, pp. 111-122. (In Russ.). DOI: 10.24411/2072-9286-2018-00026

Bakaeva, E. P. (2018c) Pervaya konferentsiya buddistov Kalmykii i Astrahanskoi oblasti: Predystoriya i resheniya (1988-1991 gody) [The First Conference of the Buddhists of Kalmykia and the Astrakhan Region: Background and Decisions (1988-1991)]. Novyi istoricheskii vestnik, no 1, pp. 71-80. (In Russ.). DOI: 10.24411/20729286-2018-00004

Baranova, V. V. (2016) Nevidimaia migratsia: puteshestvie iz Kalmykii v Moskvu [The invisible migration: A journey from Kalmykia to Moscow]. Vestnik Kalmytskogo instituta gumanitarnykh issledovanii RAN, no. 2, pp. 89-97. (In Russ.). 
Buddiiskaya traditsiya v Kalmykii i Zapadnoi Mongolii. Sakral'nye ob'ekty [The Buddhist tradition in Kalmykia and Western Mongolia. Sacred objects] (2015). Bakaeva E. P. et al. Moscow, Nauka, Vost. lit. 231 p. (In Russ.).

Guchinova, E.-B. M. (2004) Ulitsa Kalmuk road. Istoriya, kul'tura i identichnosti kalmytskoi obshchiny $v$ SShA [Kalmuk road: The history, culture and identity of the Kalmyk community in the USA]. St. Petersburg, Aleteya. 340 p. (In Russ.).

Dilova-hutuhta Mongolii. Politicheskie memuary i avtobiografiya perevoploshcheniya buddiiskogo lamy [DilovaKhutuhta Mongolia. Political memoirs and autobiography of the reincarnation of the Buddhist lama] (2018). Transl. by E. V. Gordienko. Ed. by S. L. Kuz'min, Zh. Oyuunchimeg. Lit. ed. by N. G. Inozemtseva. Moscow, Save Tibet Foundation. 352 p. (In Russ.).

Dordzhiev, V. P. (2000) Delo vsei zhizni [The work of a lifetime]. Stavropol, Stavr. Kraev. Tip. (In Russ.).

Zhukovskaya, N. L. (1988) Kategorii i simvolika traditsionnoi kul'tury mongolov [Categories and symbolism of the traditional culture of the Mongols]. Moscow, Nauka. 194 p. (In Russ.).

Ivanov, O. I. (2015) Kul'turnoe prostranstvo kak prostranstvo patternov povedeniia i myshleniia [Cultural space as a space of patterns of behavior and thinking]. Trudy Sankt-Peterburgskogo gosudarstvennogo instituta kul'tury, vol. 206, pp. 19-26. (In Russ.).

Kargina, I. G. (2014) Religiia kak faktor adaptatsii immigrantov: osobennosti amerikanskogo sluchaya [Religion as a factor in the adaptation of immigrants: features of the American case]. Polis. Politicheskie issledovaniya, no. 2, pp. 164-174. (In Russ.).

Lotman, Yu. M. (1999) Vnutri myslyashchikh mirov.: Chelovek-tekst-semiosfera-istoriya [Inside the thinking worlds: Man - text - semiosphere - history]. Moscow, Yazyky russkoy kul'tury. 458 p. (In Russ.).

Malkova, V. K. and Tishkov, V. A. (2009) Kul'tura i prostranstvo. Kniga pervaya. Obrazy rossiiskikh respublik v Internete [Culture and space. Book 1. Images of Russia's national republics on the Internet]. Moscow, Inst. of Ethnol. and Anthrop. of RAS. 150 p. (In Russ.).

Malkova, V. K. and Tishkov, V. A. (2010) Kul'tura i prostranstvo. Kniga vtoraya. Istoriko-kul'turnye brendy territorii, regionov i mest [Culture and space. Book 2. Historical and cultural brands of territories, regions and places]. Moscow, Inst. of Ethnol. and Anthrop. of RAS. 182 p. (In Russ.).

Milenkovich, T. (1998) Kalmici u Srbiji. 1920-1944 [Kalmyks in Serbia: 1920-1944]. Belgrade, Traco. 246 p. (In Serb.).

Muzraeva, D. N. (2016) Teksty Belogo startsa u oiratov i kalmykov [Texts of the White Old Man among the Oirats and Kalmyks]. In: Transgranichnaya kul'tura: ocherki sravnitel'no-sopostavitel'nogo issledovaniya traditsii zapadnykh mongolov $i$ kalmykov [Trans-border culture: A comparative study of the traditions of the Western Mongols and Kalmyks]. E. P. Bakaeva et al. Elista, Kalm. Sc. Cent. of RAS. 456 p. Pp. 294-312. (In Russ.).

Namrueva, L. V. (2011) Vliyanie migratsii molodezhi na sokhranenie etnichnosti (na primere kalmykov) [The impact of youth migration on the preservation of ethnicity (the case of the Kalmyks)]. Vestnik Rossiiskogo universiteta druzhby narodov. Seriya: Sotsiologiya, no. 2, pp. 87-92. (In Russ.).

Namrueva, L. V. (2013) Migratsionnye ustanovki molodezhi Kalmykii (po materialam issledovaniya) [Migration representations of the Kalmyk youth: A field study]. Vestnik Kalmytskogo universiteta, no. 2, pp. 64-70. (In Russ.).

Naminov-Burhinov, D. (1997) Bor'ba za grazhdanskie prava kalmytskogo naroda [The struggle for civil rights of the Kalmyk people]. Elista, Dzhangar. 181 p. (In Russ.).

Orlova E. V. (2010) Kul'turnoe prostranstvo: opredelenie, spetsifika, struktura [Cultural space: definition, specificity, structure]. Analitika kul'turologii, no. 3(18), pp. 42-53. (In Russ.).

Tishkov, V. A. (2003) Kul'turnyi smysl prostranstva [Cultural significance of space]. In: V Kongress etnografov $i$ antropologov Rossii [5th Congress of Russia's ethnographers and anthropologists] / ed. by V. A. Tishkov. Omsk, 9-12 June 2003. Moscow, Inst. of Ethnol. and Anthrop. of RAS. 380 p. Pp. 16-24. (In Russ.).

Topalova, D. (2017) The Kalmyk Expatriate Community: History of the Emergence (1920-1930s). Vestnik Kalmyckogo instituta gumanitarnyh issledovanij RAN [Bulletin of the Kalmyk Institute for Humanities] (Oriental Studies), no. 5, pp. 237-249. DOI: DOI 10.22162/2075-7794-2017-33-5-237-249 (In Russ.).

Topalova,D. (2019). Socio-Cultural Activities of the Kalmyk Expatriate Community (1920s - early 1930s). Oriental Studies, no. 2, pp. 195-206. DOI 10.22162/2619-0990-2019-42-2-195-206 (In Russ.). 
Thurman, R. (2009) Razdum'ya o zhizni dostochtimogo drepungskogo geshe Navanga Vang'yala, vyhodtsa iz Tsagan Bulukkha v Kalmykii [Thoughts on the life of the venerable Drepung Geshe Ngawang Wangyal, a native of Kalmykia's Tsagan Bulug]. Buddizm v Rossii, no. 42, pp. 59-62. (In Russ.).

Ubushaev, M. B. (2009) Migratsionnye protsessy v Respublike Kalmykiya v postsovetskii period [Migration processes in the Republic of Kalmykia in the post-Soviet period]. Vestnik Kalmytskogo instituta gumanitarnykh issledovanii RAN, no.1, pp. 65-69. (In Russ.).

Khaninova, R. M. (2008) David Kugul'tinov i Mikhail Khoninov: dialog poetov [David Kugultinov and Mikhail Khoninov: a dialogue of poets]. Elista, Kalm. State Univ. 185 p. (In Russ.)

Hopkins, J. (2009) Kalmytskii vklad v razvitie buddizma na Zapade [A Kalmyk contribution to the development of Buddhism in the West]. Buddizm v Rossii, no. 2, pp. 25-27. (In Russ.).

Chetyrova, L. B. (2010) Kalmyki: mezhdu Vostokom i Zapadom [The Kalmyks: between East and West]. In: Evraziiskii mir: tsennosti, konstanty, samoorganizatsiya [The Eurasian world: values, constants, self-organization]. Ed. by Yu. V. Popkov. Novosibirsk, Nonparel'. 449 p. Pp. 292-352. (In Russ.).

Aubin, F. (1968) Une société d'émigrée: la colonie des kalmouks en France. In: L’Année sociologique, 1966, 3-eme serie, vol.17/1966, pp.133-212. (In French).

Bakaeva, E. (2014) Research on the History of Buddhism in Kalmykia at the Present Stage. Anthropology \& Archeology of Eurasia, vol. 53, is. 4, pp. 21-46.

Bormanzhimov, A. (1987) The Kalmyks in the United States 35 Years After. Howell, NJ, Kalmyk Society in the United States. $17 \mathrm{p}$.

Herberg, W. (1960) Protestant, Catholic, Jew: An Essay in American Religious Sociology. New York, Anchor Books. 309 p.

Hirschman, Ch. (2004) The Role of Religion in the Origins and Adaptation of Immigrant Groups in the United States. International Migration Review, vol. 38, issue 3, pp. 1206-1233.

Hochron, A. and Staff, P. (2012) Buddhist Community Has Deep Roots in Howell. Temples help bring tight knit community together. Patch [online] Available at: https://patch.com/new-jersey/howell/buddhist-community-has-deep-roots-in-howell (accessed: 05.05.2019).

Rubel, P. G. (1967) The Kalmyk Mongols: a study in continuity and change / Indiana University Publications. Uralic and Altaic Series, Vol. 64. Bloomington, Indiana University; The Hague: Mouton and Co. XIV. 282 p.

Submission date: 03.06.2019. 